JAROSŁAW ROKICKI ${ }^{1}$

\title{
MIGRACJA, STUDIA I PRACA. STUDENCI Z UKRAINY W KRAKOWSKIEJ AKADEMII IM. ANDRZEJA FRYCZA MODRZEWSKIEGO
}

Słowa kluczowe: studenci ukraińscy, adaptacja, studia, Kraków

\section{UWAGI WSTĘPNE}

W świetle danych zawartych w Sprawozdaniu o studiach wyższych, przygotowanym dla Głównego Urzędu Statystycznego i zaktualizowanym według stanu z 31 listopada 2015 roku, w Krakowskiej Akademii im. Andrzeja Frycza Modrzewskiego (KAAFM) studiowało w trybie stacjonarnym i niestacjonarnym w sumie 2140 cudzoziemców z 31 krajów, spośród których 2034 osoby przyjechały z Ukrainy. Jak łatwo policzyć, ci ostatni stanowili $95 \%$ wszystkich studentów obcokrajowców uczących się w akademii. Z punktu widzenia uczelni kształcenie obcokrajowców, choć nie zdejmuje z niej odpowiedzialności za edukację 106 studentów z innych państw, skoncentrowane jest w sposób oczywisty na obywatelach Ukrainy. Dotyczy to zresztą nie tylko Krakowskiej Akademii, ale w ogóle kształcenia cudzoziemców w Polsce ${ }^{2}$. Dla polskiego szkolnictwa wyższego oznacza to, że ranga i przyszłość edukacji międzynarodowej w dużej mierze zależy od umiejętności ułożenia współpracy pomiędzy ukraińskim klientem i polskim

${ }^{1}$ Dr hab., prof. KAAFM; Krakowska Akademia im. Andrzeja Frycza Modrzewskiego; ORCID: 0000-0002-5156-8208; e-mail: urrokick@cyf-kr.edu.pl.

${ }^{2}$ Według danych GUS (stan z 31 listopada 2014 roku) obywatele Ukrainy (23 392 osoby) stanowią na polskich uczelniach $50,74 \%$ wszystkich studentów obcokrajowców (46 101 osób). Podaję za: http://www.studyinpoland.pl/konsorcjum/images/stories/115_2015_newsletter/raport-studenci-zagraniczni-tabela.pdf (dostęp 7 IX 2016). 
usługodawcą - na poziomie instytucji, ale przede wszystkim w bezpośrednich kontaktach między ludźmi - Polakami i Ukraińcami. By ująć to w szerszym kontekście: $z$ jednej strony studiowanie w kraju o odmiennej kulturze i w języku innym od ojczystego, a z drugiej uczenie ludzi, których proces socjalizacji przebiegał w odmiennych warunkach społecznych i w różniącym się od "naszego" kodzie kulturowym, sprawia, że studiowanie i uczenie stają się jednymi z najbardziej realnych doświadczeń wielokulturowości. Ta zaś, obecnie uznawana za zjawisko kontrowersyjne, aktywnie towarzyszy rozwojowi ludzkości "od zawsze” i mimo strachu przed obcym, oporu, wyszydzania i negatywnej stygmatyzacji „innego" jest nieuchronna i w długim przekroju czasowym wzbogaca nasze człowieczeństwo ${ }^{3}$.

Zdając sobie sprawę ze złożoności zagadnienia, oczekiwań i nadziei studentów oraz wykładowców, nieuchronności problemów adaptacyjnych, niepewności spotkania z „innym”, bagażu historycznie ukształtowanych, odwzajemnianych stereotypów i uprzedzeń oraz wielu często niezdefiniowanych i nieoczekiwanych czynników, w lutym 2016 roku Rektor Krakowskiej Akademii im. Andrzeja Frycza Modrzewskiego prof. dr hab. Jerzy Malec powołał Komisję ds. Studentów Obcokrajowców, która miała się zająć - najogólniej mówiąc - zdarzeniami wynikającymi z kontaktu międzykulturowego oraz zarządzaniem nimi, w tym wspomaganiem procesów adaptacyjnych i integracyjnych studentów w nowym środowisku. Celem tych działań było udoskonalenie pracy uczelni z obcokrajowcami, zwłaszcza ze studentami z Ukrainy, i uczynienie z niej sprawnej instytucji w systemie kształcenia międzynarodowego.

Jedną z najważniejszych potrzeb komisji stało się uzyskanie z konieczności wstępnych, ale wiarygodnych, empirycznych i bezpośrednich informacji o naszych studentach - nie tylko danych osobowych, zapisanych w dokumentach Działu Rekrutacji, ale też wiedzy na temat oczekiwań i motywów wyboru studiów, doświadczeń pobytu w Polsce, mieszkania w Krakowie, studiowania „we Fryczu”, wreszcie kontaktu z Polakami. Cel ten można było osiągnąć organizując badania sondażowe wśród studentów obcokrajowców kształcących się w KAAFM. Pilotaż ankiety badawczej, w którym kwestionariusze rozdano wylosowanym 25 osobom z prośbą o wypełnienie i zwrot w ciągu tygodnia, po przeszło dwóch tygodniach

${ }^{3}$ Zob. m.in. J. Rokicki, O realności i złudzeniu „globalizacji”, „wielokulturowości” $i$ „ponowoczesności”, [w:] Wzory wielokulturowości we współczesnym świecie, red. K. Golemo, T. Paleczny, E. Wiącek, Kraków 2006, s. 25-38. 
oczekiwania - zgodnie z umiarkowanymi obawami - zakończył się napływem sześciu wypełnionych (niektórych dość pobieżnie) egzemplarzy. Zniechęcający rezultat pilotażu sprawił, że niezbędne stało się w tych warunkach skorzystanie z dobrodziejstw techniki ankiety audytoryjnej. Dzięki uprzejmości wykładowców studenci mogli odpowiedzieć na pytania kwestionariusza w sali wykładowej w czasie wygospodarowanym na zajęciach.

W tym miejscu chciałbym serdecznie podziękować za pomoc: w organizacji zbierania danych - prof. dr. hab. Hieronimowi Kubiakowi, prof. nadzw. dr. hab. Dariuszowi Fatule, dr. Tomaszowi Trafasowi; w tłumaczeniu kwestionariusza na język ukraiński oraz wypowiedzi studentów z ukraińskiego i rosyjskiego na polski - prof. nadzw. dr hab. Olenie Bocharovej; a prof. nadzw. dr hab. Beacie Molo oraz prof. dr. hab. Edwardowi Cziomerowi za umożliwienie (mimo późnego zgłoszenia) prezentacji wstępnych wyników badań podczas XVI konferencji naukowej „Państwo, gospodarka, społeczeństwo" 7 czerwca 2016 roku na posiedzeniu sesji tematycznej $W y$ zwania dla bezpieczeństwa i współpracy międzynarodowej w XXI wieku-ze szczególnym uwzględnieniem nielegalnej migracji. Przede wszystkim jednak serdecznie dziekuję studentom z Ukrainy za wypełnienie kwestionariuszy ankiety, życzliwe dyskusje na temat studiów w KAAFM, życia w Krakowie, kontaktów z Polakami i kilku innych ważnych spraw. Bez tego, a zwłaszcza przychylności, cierpliwości i poświęcenia cennego czasu, realizacja sondażu byłaby niemożliwa, a co najmniej znacznie trudniejsza.

Efektem tych badań jest poniższe opracowanie. Powstało ono na podstawie odpowiedzi 98 studentów z Ukrainy na pytania kwestionariusza ankiety audytoryjnej wypełnianej pomiędzy 21 kwietnia a 16 maja 2016 roku (92 ankiety) oraz 14 czerwca (6 ankiet). Ogółem daje to korpus 98 kwestionariuszy zakwalifikowanych do opisu i analizy. Dodać jednak należy, że łącznie z pilotażowymi 25 kopiami rozdanych zostało 145 kwestionariuszy. Ze 120 sztuk rozdanych w trakcie badań audytoryjnych ostatecznie do opracowania weszły 82 kwestionariusze wypełnione w języku polskim, 8 po angielsku (od studentów studiujących na kursach anglojęzycznych w KAAFM), 6 po ukraińsku i 2 w języku rosyjskim, co razem daje 98 egzemplarzy. Brakujące 22 egzemplarze albo w ogóle do mnie nie wróciły, albo zostały zwrócone jako niewypełnione lub wypełnione w stopniu niewielkim. Nie wszystkie częściowo wypełnione ankiety były jednak dyskwalifikowane. Niektóre zawierały bowiem odpowiedzi na pytania ważne z punktu widzenia uczelni i założonych celów badawczych. Konsekwencją takiej decyzji jest to, że w przypadku niektórych tabel i podawanych liczebności $\mathrm{N}$ nie równa 
się całkowitej liczbie respondentów czy zebranych i zakwalifikowanych do analizy kwestionariuszy, ale jest rzeczywistą liczbą odpowiedzi udzielonych na dane pytanie. Danych uzyskanych na podstawie tej próby nie należy traktować jako reprezentatywnych pod względem statystycznym dla całej grupy studentów Krakowskiej Akademii pochodzących z Ukrainy, których w czasie przeprowadzania badań było nieco ponad 2 tysiące (2034), chociaż zapewne można z nich wyliczyć podstawowe współczynniki statystyczne, w tym współczynniki istotności i ufności. Dane te mają jednak walor reprezentatywności typologicznej (są w istocie próbą kwotową zawierającą 4,8\% wszystkich studentów z Ukrainy uczących się w KAAFM). Można je traktować jako elementy charakterystyki zbioru, do którego opisu i analizy dało się przystąpić bez wyraźnych założeń wstępnych - uzyskano co prawda pobieżny, ale rzeczywisty obraz faktów, realne wypowiedzi prezentujące poglądy i przekonania członków badanej zbiorowości.

Zanim jednak przejdę do opisu uzyskanych wyników, chciałbym podzielić się pewną refleksją, która była pochodną niepokoju wywołanego już po pobieżnym spojrzeniu na wypełnione kwestionariusze ankiety. Otóż na pierwszej stronie, w pierwszym pytaniu, w pierwszej kafeterii (tj. przy pierwszej opcji z listy możliwych odpowiedzi) czworo respondentów poprawiło moje sformułowanie $z$ "przedstawiciela KAAFM na Ukrainie” na „przedstawiciela KAAFM w Ukrainie”, przypominając mi, że Ukraina jest niepodległym państwem, a nie ziemią lub regionem ${ }^{4}$. I studenci mieli oczywiście rację, co potwierdził wymieniony w odsyłaczu prof. Mirosław Bańko z Uniwersytetu Warszawskiego, a w zakamarkach mej pamięci wyświetliła się na czerwono sentencja, poświęcona co prawda lekarzowi, ale przydatna także dla socjologa: medice, cura te ipsum.

\section{UWAGA STATYSTYCZNA}

Próba badawcza, tzn. liczba respondentów, których kwestionariusze zostały zakwalifikowane do analizy, obejmuje 98 osób. Dziewięćdziesiąt osiem nie równa się sto, ale jest bardzo bliskie stu. Dobrym zwyczajem w posługiwaniu się danymi procentowymi jest przy tym niepodawanie proporcji

\footnotetext{
${ }^{4}$ Zob. M. Bańko, W Ukrainie czy na Ukrainie?, http://sjp.pwn.pl/poradnia/haslo/ w-Ukrainie-czy-na-Ukrainie;16214.html (dostęp 5 VI 2016). W artykule konsekwentnie posługuję się przyimkiem „w”.
} 
w procentach w zbiorze mniejszym od stu, ponieważ jednostka (cokolwiek by to było) jest większa od jednego procentu. Idąc tym tropem, w przypadkach, gdy proporcja jest liczona w stosunku do $\mathrm{N}=98$, nie podaję danych procentowych, ponieważ ich sens jest wątpliwy. Wartość bezwzględna jest bowiem tak bliska proporcji podanej w procentach, że grozi niemal śmiesznością, kulminującą na przykład w stwierdzeniu, że 10 osób (10\%) na dane pytanie odpowiedziało twierdząco. Tam jednak, gdzie $\mathrm{N}$ jest inne niż liczba respondentów (np. jest liczbą odpowiedzi udzielonych na dane pytanie, a można było wybrać więcej niż jedną odpowiedź), proporcje będą podawane w procentach.

\section{PODSTAWOWE CHARAKTERYSTYKI PRÓBY BADAWCZEJ}

Wiek

Wszyscy badani mieszczą się w przedziale wiekowym od 16 do 27 lat, przy czym zdecydowana większość ma 17-20 lat (81 studentów), 1 osoba ma 16 lat, a pozostałych 16 respondentów - od 21 do 27 lat. Dla porównania warto zauważyć, że w populacji wszystkich studentów cudzoziemców ${ }^{5}$ w KAAFM 14 osób miało więcej niż 27 lat, w przedziale od 17 do 20 lat znalazło się 1181 studentów, co stanowi 57,8\%, a pomiędzy ukończonym 21. i 27. rokiem życia było 706 studentów $(34,6 \%)$. Porównania te pokazują, że próba badawcza jest wyraźnie młodsza od populacji wszystkich studentów cudzoziemców. Potwierdza to proporcja studentów na poszczególnych latach studiów. W próbie badawczej 71 (74\%) studentów było na I roku, 16 (16,7\%) na II roku, a 9 (9,4\%) na III roku studiów (razem: 96). W dwóch przypadkach respondenci powstrzymali się od odpowiedzi na to pytanie. Wyraźnie niższy wiek uczestników próby badawczej w stosunku do całej populacji studentów może znacząco różnicować wiele danych, zwłaszcza tych, które dotyczą stopnia zaawansowania procesu adaptacji, częstości i stabilności kontaktów z Polakami, a nawet (w przypadku studentów I roku) wpływać na opinie wyrażane w końcówce krytycznej fazy szoku kulturowego (szoku

\footnotetext{
${ }^{5}$ Niestety nie dysponuję szczegółowymi danymi na temat wieku wszystkich studentów z Ukrainy. Pamiętając jednak, że stanowią oni około 95\% wszystkich cudzoziemców studiujących w Krakowskiej Akademii, można domniemywać, że różnice pomiędzy nimi nie mogą być duże.
} 
właściwego, fazy negocjacji), która według autora teorii szoku kulturowego, Kalervo Oberga, przypada na 3-7 miesiąc pobytu obcokrajowca w nowym, odmiennym od własnego środowisku kulturowym. Następna faza (adaptacji, przystosowania) charakteryzuje okres 6-12 miesiąca w obcym kraju6 .

Płeć

W zbiorze 98 osób znalazło się 61 kobiet i 33 mężczyzn. Czworo respondentów nie zaznaczyło kategorii płci.

\section{Obywatelstwo}

Dziewięćdziesięcioro czworo respondentów to obywatele Ukrainy, jeden ma obywatelstwo innego kraju, w dwóch przypadkach jako kategorię obywatelstwa podano nazwę miasta ${ }^{7}$, w którym respondenci mieszkali w Ukrainie, a jedna osoba nie wypełniła stosownej rubryki.

\section{Język i tożsamość narodowa}

W części opracowania opisującej język i tożsamość narodową badanych N wynosi: 92 dla kategorii języka, ponieważ spośród 98 kwestionariuszy

${ }^{6}$ Zwięzły, ale poprawny opis teorii szoku kulturowego można znaleźć w angielskojęzycznej wersji Wikipedii (https://en.wikipedia.org/wiki/Culture_shock, dostęp 7 IX 2016). Kalervo Oberg (1901-1973) był amerykańskim antropologiem kulturowym. Pojęcie szoku kulturowego sformułował w czasie pobytu dydaktyczno-badawczego w Brazylii w latach 1946-1958 - służyło ono jako kategoria opisująca ciąg zmieniających się z upływem czasu zachowań i postaw amerykańskich specjalistów wysłanych do pracy w Brazylii. Szok prowadził od „euforii i podniecenia pracą w obcym kraju, które szybko przeszły w depresję, rozczarowanie i ostry krytycyzm brazylijskich metod działania, problemy ze zdrowiem, by w trakcie leczenia przejść w fazę akceptacji i przystosowania się do nowych warunków życia". Oberg zastosował pojęcie po raz pierwszy w nieformalnym odczycie wygłoszonym w 1954 w Rio de Janeiro w klubie dla żon pracowników amerykańskich. Odczyt ten został opublikowany dopiero w roku 1960 jako 1954 Culture Shock w serii „Bobbs-Merrill Reprint Series in the Social Sciences”, A-329. Przedruk: „Practical Anthropology" 1960, nr 7, s. 177-182. Rok 1954 oczywiście nie jest datą druku, ale pierwszego publicznego przedstawienia tej teorii. Powyższe informacje oraz cytat podaję za: „American Anthropologist” 1974, nr 76 (2), http://onlinelibrary.wiley.com/doi/10.1525/ aa.1974.76.2.02a00260/pdf (dostęp 7 IX 2016).

${ }^{7}$ Prawdopodobnie z powodu wieloznaczności słownikowego tłumaczenia terminu na громадянство, со bez dodatkowego uściślenia może oznaczać także „miejsce zamieszkania" w znaczeniu miejscowości, a nie państwa. 
do badań zakwalifikowano odpowiedzi 92 osób, które odniosły się do tego pytania, i 72 dla kategorii tożsamości narodowej. Oznacza to, że odpowiednio 6 i 26 osób na te pytania nie odpowiedziało. Niestety kwestionariusz nie pozwolił na uzyskanie informacji na temat przyczyn braku odpowiedzi w odniesieniu do obu kategorii.

Językiem używanym $w$ domu rodzinnym respondentów w 58 przypadkach jest ukraiński, w 46 - rosyjski, a w 3 ankietach obok rosyjskiego lub ukraińskiego podano także język polski. Suma wynosi 107, ale nie odnosi się ona do respondentów - jest wyłącznie liczbą aktów deklaracji w stosunku do wymienianych trzech języków domowych (w 16 przypadkach respondenci wskazywali na więcej niż jeden język domowy). Jeśli chodzi o respondentów, to wyłącznie po ukraińsku rozmawia w domu 40 osób, wyłącznie po rosyjsku - 24, a równolegle językami ukraińskim i rosyjskim posługuje się 18 badanych. Ponadto 3 osoby mówią w domu jednocześnie po polsku w zestawieniu z rosyjskim lub ukraińskim. W 7 przypadkach respondenci nie podali informacji na temat języka, jakim posługują się w domu.

Tożsamość narodową określono na podstawie odpowiedzi na pytanie, które zostało sformułowane w sposób następujący: „Czuję, że jestem (w miejsce wykropkowane proszę wpisać narodowość, z którq się Pan/Pani utożsamia)". Oznacza to, że odpowiedź pochodziła wyłącznie od respondenta i w żaden sposób nie była sugerowana w kwestionariuszu, np. poprzez zamieszczenie kafeterii. $W$ odpowiedzi na to pytanie 58 studentów określiło swą tożsamość narodową jako ukraińską, 2 jako polską, 1 jako norweską, 1 jako białoruską, 2 jako „słowiańską”, 1 jako „europejską", a 7 podało odpowiedzi dające się zaklasyfikować $w$ ramach pojęcia „kosmopolita”. Mieszczą się tu między innymi takie sformułowania:

[jestem] „obywatelem świata”, „kosmopolitą”, „Nie uważam, że jestem kimś z narodowości, mieszkam na ziemi”, „człowiekiem, dla którego narodowość kogokolwiek nie ma znaczenia”, „nie rozumiem podziału na narodowość"8.

Powtórzmy, że sumuje się to do 72 odpowiedzi, co oznacza, że 20 (a w odniesieniu do wszystkich rozdanych kwestionariuszy - 26) osób nie odpowiedziało na pytanie o tożsamość narodową.

\footnotetext{
${ }^{8}$ Większość cytatów z kwestionariusza pozostawiam w wersji oryginalnej - tak jak napisali respondenci. Poprawiam jednak rażące lub ośmieszające błędy.
} 
Interesujący materiał analityczny daje skrzyżowanie kryterium języka domowego (rodzinnego) z poczuciem tożsamości narodowej. Dane te zawiera tabela 1.

Tabela 1. Język domowy/rodzinny a poczucie tożsamości narodowej

\begin{tabular}{|c|c|c|c|c|c|c|c|c|c|}
\hline \multirow[b]{2}{*}{ Język } & \multicolumn{9}{|c|}{ Tożsamość } \\
\hline & 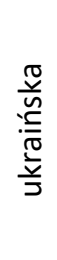 & $\frac{\frac{0}{0}}{\frac{0}{20}}$ & 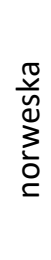 & $\begin{array}{l}\frac{\pi}{0} \\
\frac{\pi}{3} \\
\frac{0}{0} \\
\frac{0}{0} \\
\frac{\pi}{0}\end{array}$ & $\begin{array}{l}= \\
\frac{\pi}{n} \\
\frac{n}{c} \\
\frac{\pi}{3} \\
\frac{0}{\omega} \\
\frac{0}{n}\end{array}$ & 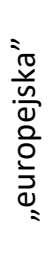 & 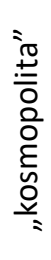 & $\begin{array}{l}\bar{N} \\
\frac{\pi}{0} \\
\frac{0}{3} \\
0 \\
\frac{0}{0} \\
0 \\
\frac{1}{0} \\
\frac{0}{0}\end{array}$ & 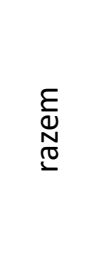 \\
\hline Tylko ukraiński & 27 & 1 & & & 1 & 1 & 2 & 8 & 40 \\
\hline Tylko rosyjski & 15 & 1 & 1 & 1 & 1 & & 3 & 2 & 24 \\
\hline Ukraiński i rosyjski & 14 & & & & & & 2 & 2 & 18 \\
\hline Polski i rosyjski & 1 & & & & & & & 1 & 2 \\
\hline $\begin{array}{l}\text { Polski, rosyjski } \\
\text { i ukraiński }\end{array}$ & 1 & & & & & & & & 1 \\
\hline Brak odpowiedzi & & & & & & & & 7 & 7 \\
\hline Razem & 58 & 2 & 1 & 1 & 2 & 1 & 7 & 20 & $92 / 92$ \\
\hline
\end{tabular}

Zauważmy, że w badanym przypadku kryterium tożsamości narodowej nie jest silnie związane z kryterium językowym. Spośród 58 respondentów jednoznacznie deklarujących swą tożsamość jako ukraińską wyłącznie językiem ukraińskim jako językiem domowym posługuje się 27 badanych (46,6\%). Wyłącznie po rosyjsku mówi 15 osób $(25,9 \%)$, a 14 (24,1\%) używa obu języków. Spośród 15 respondentów mówiących w domu po rosyjsku ani jeden nie określił swojej tożsamości jako rosyjskiej, ale 4 spośród 10 określających swoją tożsamość w kategoriach innych niż narodowe za swój język domowy uznaje rosyjski. Na uwagę zasługuje również to, że mniej więcej co piąty respondent (20 osób) - w tym 8 osób mówiących w domu wyłącznie po ukraińsku - nie odpowiedział na pytanie o tożsamość narodową. Wyniki te można odczytać jako sugestie tego, że:

- język życia codziennego nie jest jednoznacznie powiązany z tożsamością narodową, a wśród studentów widoczna jest grupa rosyjskojęzycznych Ukraińców, 
- co piąty respondent mówi w domu dwoma językami - najczęściej jest to język ukraiński i rosyjski,

- widoczna jest grupa, która nie chce się jednoznacznie identyfikować z żadną narodowością.

Sugestie te $z$ punktu widzenia statystyki jako metody badawczej można uznać za zupełnie przypadkowe. Biorąc jednak pod uwagę, że znaczna część studentów KAAFM pochodzi ze wschodniej Ukrainy, trzeba powiedzieć, że być może nie całkiem przypadkowo ujawnia się ułamek mało znanej, a bardzo skomplikowanej sytuacji językowo-tożsamościowej mieszkańców tej części kraju.

Warunki mieszkaniowe

W akademiku mieszkało 37 studentów, u rodziny lub przyjaciół - 3, w samodzielnie wynajętym pokoju - 10, w wynajętym pokoju dzielonym z innymi osobami - 16, samodzielnie w wynajętym mieszkaniu - 6 , w wynajętym mieszkaniu razem $z$ innymi osobami - 20, w mieszkaniu własnym lub należącym do rodziny lub przyjaciół - 1 (razem 93, co oznacza, że 5 respondentów nie odpowiedziało na pytanie o warunki mieszkaniowe podczas studiów w KAAFM w okresie od kwietnia do czerwca 2016 roku).

Warunki materialne

Ostatnie pytanie „metryczki” miało na celu określenie statusu materialnego studenta, subiektywnie ocenianego przez respondentów poprzez wybór odpowiedzi precyzujących, na ile środki otrzymywane od rodziny lub ze stypendium wystarczają na pokrycie kosztów studiów i utrzymania. Jednocześnie wprowadziłem pytanie dotyczące potrzeby podejmowania przez studentów pracy zarobkowej w Polsce, pozwalającej na uzupełnienie zasobów finansowych i kontynuację studiów. Nadałem mu formę, która pozwalała na wyrażenie opinii w sposób niebędący jednocześnie deklaracją bądź potwierdzeniem podjęcia takiej pracy przez respondenta.

Przy pytaniu "Czy pieniądze otrzymywane od rodziny bądź ze stypendium wystarczają na pokrycie kosztów studiów i utrzymania się w Polsce?":

- 46 osób odpowiedziało twierdząco,

- 11 osób uznało, że środki te są niewystarczające,

- a 34 respondentów stwierdziło, że „podjęcie pracy umożliwia pokrycie kosztów studiów i utrzymania się w Polsce". 
Daje to w sumie 91 odpowiedzi, co oznacza, że na to pytanie nie odpowiedziało 7 osób.

Pierwszą refleksją, jaka się tu nasuwa, jest to, że nieco mniej niż połowa badanych pokrywa koszty studiów i utrzymuje się w Polsce ze środków otrzymywanych ze źródeł zewnętrznych (rodzina lub stypendium) - to 46 odpowiedzi. Obok tego 11 respondentów przyznało, że nie są oni w stanie pokryć tych niezbędnych kosztów ze stypendiów bądź środków otrzymywanych od rodzin, a 34 zgodziło się z opinią, że podjęcie pracy może uzupełnić brakujące środki. Wynika z tego, że kształceni w KAAFM studenci z Ukrainy w żaden sposób nie stanowią obciążenia dla polskiego podatnika, a ci, którym środki ze stypendiów bądź od rodzin nie wystarczają na pokrycie kosztów nauki i pobytu Polsce, są zdecydowani podjąć pracę zarobkową, która pozwoli im na kontynuację studiów. Z odpowiedzi na pytanie ankiety nie wynika jednoznacznie, czy praca ta ma być podejmowana w Polsce czy też w innym kraju.

\section{II. ŹRÓDŁA INFORMACJI O STUDIACH}

Najczęściej wskazywanym źródłem informacji o studiach, które w efekcie wybrali respondenci, jest internet - 52 wskazania; dalej lokują się „inni studenci uczący się w KAAFM" - 31 wskazań, a pierwszą trójkę zamykają „przedstawiciele KAAFM w Ukrainie”, wśród których mieszczą się „rekruterzy" 124 odpowiedzi. Za nimi plasują się „studenci uczący się w Polsce”, ale w innych szkołach niż KAAFM - 13 odpowiedzi, i „znajomi niebędący jednocześnie członkami rodziny" - 12 odpowiedzi. Te pięć kategorii sumuje się do 132 wskazań, co stanowi niemal 85\% wszystkich 156 odpowiedzi ( $N=156$, ponieważ respondenci mogli wskazać i wskazywali więcej niż jedno źródło informacji). Pozostałe odpowiedzi to: członkowie rodziny - 4, targi edukacyjne -3 , plakat -3 , inne osoby -3 , środki masowego przekazu (prasa, radio, telewizja) -3 , inni studenci, nieuczący się w Polsce -3 , oraz źródła inne niż wymienione w kafeteriach załączonych do pytania -5 .

\footnotetext{
${ }^{9}$ Nazwa „rekruterzy”, używana potocznie w środowisku uczelnianym, nie pojawia się w pytaniu ankiety, ponieważ dla respondentów jest ona aksjologicznie nieobojętna. „Rekruter” jest raczej postrzegany jako ktoś, kto reprezentuje uczelnię, chociaż - jak się dowiadujemy - nie zawsze działa za jej zgodą bądź z jej upoważnienia, ale jedynie w interesie własnym lub zatrudniającej go firmy, zwłaszcza wtedy, kiedy za taką informację pobierana jest opłata.
} 


\section{MOTYWY WYBORU MIEJSCA STUDIÓW}

Ogólne pytanie o motywy wyboru miejsca studiów zostało rozłożone na trzy części: pytanie o wybór kraju (Polski), miasta (Krakowa) oraz uczelni (KAAFM). Wszystkie trzy pytania zadano w formie otwartej, a zatem respondent nie wybierał z kafeterii zamkniętych możliwości, ale swój motyw musiał samodzielnie określić i nazwać. Część odpowiedzi powtarza się w tych trzech pytaniach, ponieważ motywacje respondentów w ich świadomości nie były analitycznie rozdzielane. Podział ten jest zabiegiem badacza, a nie badanego. Na tym poziomie opisu podaję je $w$ taki sposób, w jaki zostały przyporządkowane poszczególnym pytaniom. Należy dodać, że w tym miejscu w przypadku każdej części pytania $\mathrm{N}$ jest wyraźnie różna (większa od liczby respondentów), ponieważ studenci mogli wymienić dowolną ilość subiektywnie dostrzeganych przyczyn czy motywów, dla których wybrali Polskę jako kraj, Kraków jako miasto, a Krakowską Akademię im. Andrzeja Frycza Modrzewskiego jako uczelnię. Proporcje odpowiedzi (wyrażone w procentach) należało zatem obliczać w stosunku do całkowitej sumy wskazań (odpowiednio 168 dla kraju, 112 dla miasta i 146 dla uczelni), a nie w stosunku do liczby kwestionariuszy zakwalifikowanych do analizy (98) . Lista uporządkowanych w powyższy sposób motywów przedstawia się następująco.

Motywy decydujące o podjęciu studiów w Polsce $(N=168)$

1. Możliwość otrzymania dyplomu europejskiego - $36(21,4 \%)$

2. Wysoki poziom studiów w Polsce - 24 (14,3\%)

3. Lepsza przyszłość i praca w Europie - $18(10,7 \%)$

4. Dobra, przystępna cena studiów - $15(8,9 \%)$

5. Geograficzna bliskość Ukrainy - $14(8,3 \%)$

6. Doświadczenie życia za granicą - $12(7,1 \%)$

7. Lepsze życie w Polsce - 9 (5,4\%)

8. Dobre miejsce startu w dorosłe życie $-8(4,8 \%)$

9. Możliwość swobodnego podróżowania po Europie - $8(4,8 \%)$

10. Brak korupcji w porównaniu z Ukrainą - 6 (3,6\%)

11. Atrakcyjność i piękno kraju (Polski) - $4(2,4 \%)$

12. Brak egzaminu wstępnego - $3(1,8 \%)$ 
13. Podobieństwo języka i kultury - 2 (1,2\%)

14. Inne - $9(5,4 \%)^{10}$

Motywy decydujące o podjęciu studiów w Krakowie $(\mathrm{N}=112)$

1. Piękne, ciekawe miasto kultury, architektury, historii - $40(35,7 \%)$

2. Tu mieści się KAAFM - $15(13,4 \%)$

3. „Podoba mi się" - 14 (12,5\%)

4. Miasto studentów - 9 (8\%)

5. Tu mam znajomych, kolegów, członków rodziny - 9 (8\%)

6. Blisko do domu $-8(7,1 \%)$

7. Znałem/znałam to miasto wcześniej - 7 (6,3\%)

8. Rozwija się, młode miasto $-5(4,5 \%)$

9. Miasto możliwości - 4 (3,6\%)

10. Inne - 1 (0,9\%) („nie lubię Warszawy”)

Motywy decydujące o podjęciu studiów w KAAFM ( $\mathrm{N}=146)$

1. Dobra, przystępna cena - $27(18,5 \%)$

2. Liczba i różnorodność kierunków i specjalności, możliwości wyboru, ciekawy profil studiów - 26 (17,8\%)

3. Dobra infrastruktura, jaką oferuje Akademia - 15 (10,3\%)

4. „Podoba mi się" - 13 (8,9\%)

5. Dobrzy, kompetentni i przyjaźni wykładowcy - 10 (6,8\%)

6. Wysoki poziom nauczania $-9(6,1 \%)$

7. Dużo znajomych, wcześniejsza współpraca - $10(6,8 \%)$

8. Pozytywne opinie o uczelni, „dobra reputacja” - 7 (4,8\%)

9. Nowoczesna uczelnia $-7(4,8 \%)$

10. Studia w języku angielskim - $6(4,1 \%)$

11. Studiuje dużo Ukraińców - 6 (4,1\%)

12. Brak egzaminu wstępnego, łatwość zaliczania przedmiotów $-4(2,7 \%)$

13. Najlepszy wybór spośród sprawdzanych ofert - 3 (2,1\%)

14. Niepotrzebna Karta Polaka - $2(1,4 \%)$

15. Inne - 1 (0,7\%) („,przypadek”)

${ }^{10}$ Znalazły się tu pojedyncze odpowiedzi, np.: ciekawość, możliwości rozwoju, nauczyciele, studia w języku angielskim, szeroki zakres programów, możliwość samorealizacji, wilgotny klimat. 
Motywy podjęcia decyzji o studiowaniu, podzielone w badanej próbie w relacji do trzech obszarów: kraju, miasta i uczelni, dają się dodatkowo zagregować w obrębie czy wewnątrz tych wydzielonych obszarów. W konsekwencji tego zabiegu okazuje się, że decyzje o studiowaniu w Polsce są $w$ istocie pochodną trzech lub nawet czterech różnych perspektyw postrzegania Polski. W zbiorze argumentów za wyborem Krakowa jako miasta studiów wyodrębnić można cztery rodzaje motywacji, a w zbiorze motywów decydujących o wyborze Krakowskiej Akademii nawet osiem. Zebrane kategorie motywów w większości wypowiedzi rzeczywiście odnoszą się do kontekstu zawartego w pytaniu (Polski, Krakowa, uczelni). W każdym z tych trzech kontekstów pojawiają się jednak także niemal identyczne typy motywów, które w istocie rzeczywiście mogą dotyczyć indywidualnie każdego z nich z osobna albo wszystkich razem, albo nawet żadnego, bądź też wyrażać po prostu pewną uogólnioną postawę respondenta. Chodzi tu o motywacje o charakterze praktycznym, takim jak koszt studiowania i utrzymania, względnie przewidywalny stopień trudności uzyskania dyplomu, konkurencyjność, mieszkające w Polsce lub Krakowie bliskie osoby oraz ich opinie, doświadczenia i sugestie. Ponieważ ten typ motywów pojawia się w osobnych wypowiedziach w odniesieniu do każdego z interesujących nas obszarów, powinien także zostać uwzględniony przy każdym z analizowanych kontekstów.

Wybór Polski jako kraju studiowania

Analiza motywów wyboru Polski jako miejsca studiów ujawnia cztery odrębne perspektywy, z których respondenci patrzą na nasz kraj. Perspektywa pierwsza odnosi się do Polski postrzeganej przez pryzmat przynależności do Unii Europejskiej, druga pokazuje Polskę jako kraj atrakcyjny niejako immanentnie, by nie rzec autotelicznie, co oznacza, że bez wzgledu na inne konteksty jest ona "sama w sobie" na tyle interesująca, by podjąć tu studia, trzecia odnosi się raczej do "zagranicy”, jako obszaru atrakcyjnego, nowego doświadczenia, przeciwstawianego „krajowemu”, znanemu, a ponieważ Polska jest „zagranicą”, staje się atrakcyjna. Czwarta perspektywa dotyczy wspomnianych powyżej atrybutów „praktycznych”.

- Europejska atrakcyjność Polski

Spośród czterech wspomnianych perspektyw postrzegania Polski jako dobrego miejsca studiowania w pierwszej z nich atrakcyjność Polski wynika z atrakcyjności Europy, w której umieszczana jest Polska. W tym kontekście należy interpretować motywy oznaczone na liście numerami 1, 3 i 9. 
Powtórzmy w tym miejscu, że motywy zgrupowane w zbiorze odpowiedzi oznaczonym numerem 1 to „możliwość otrzymania dyplomu europejskiego", co oznacza uznanie dyplomu ukończenia studiów w krajach Unii Europejskiej. W zbiorze numer 2 mieszczą się przekonania o perspektywie lepszej przyszłości i pracy w Europie w porównaniu z - tu posłużę się niedopowiedzeniem - obecną sytuacją w Ukrainie. Zbiór numer 9 skupia motywy bardziej praktyczne, a mianowicie to, że status studenta uczelni polskiej daje zainteresowanym „możliwość swobodnego podróżowania po Europie". Odpowiedzi sygnalizujące wybór studiów w Polsce dlatego, że - najogólniej mówiąc - otwiera on studentom z Ukrainy bramy do Europy, pojawiają się w sumie 62 razy, co stanowi $37 \%$ wszystkich odpowiedzi uzasadniających wybór kraju studiów i plasuje tę przyczynę na pierwszym miejscu w hierarchii.

- Immanentna atrakcyjność Polski

Na drugim miejscu znalazła się grupa cech, które można określić mianem „immanentnej atrakcyjności Polski”, związanej nie z jej położeniem geograficznym czy politycznym, ale z różnymi kategoriami wynikającymi z istoty jej systemu społecznego, politycznego czy kulturowego. Za zbiory tego typu motywów uznałem odpowiedzi oznaczone numerami 2, 5, 7, 10, 11 i 13. Przypomnijmy, jakie wskazania kryją się za wymienionymi numerami. Zbiór oznaczony numerem 2 to "wysoki poziom studiów w Polsce”, 5 - „geograficzna bliskość Ukrainy”, 7 - „lepsze życie w Polsce”, 10 - „brak korupcji w porównaniu z Ukrainą", 11 - „atrakcyjność i piękno kraju”, oraz 13 - „podobieństwo języka i kultury” (polskich i ukraińskich). Te zbiory zawierają w sumie 59 odpowiedzi, co stanowi 35,2\% uzasadnień wyboru Polski. Należy dodać, że w 8 wypowiedziach respondenci uznali Polskę za "dobre miejsce startu w dorosłe życie” $(4,8 \%)$, ale ponieważ te wskazania pojawiają się w kontekście Polski jako reprezentanta szerszej kategorii „zagranicy", zostały przeniesione do następnej grupy cech charakteryzujących wybór miejsca studiów.

- Atrakcyjność Polski jako „zagranicy”

W świetle 20 odpowiedzi (11,9\%) Polska studentom z Ukrainy jawi się przede wszystkim jako emanacja szerszej kategorii „zagranicy”, niekiedy w towarzystwie innych argumentów za wyborem naszego kraju na miejsce nauki. Spośród tych 20 wskazań większość, bo 12 (w stosunku do ogółu wypowiedzi - 7,1\%), podkreśla oczekiwane korzyści wynikające 
$\mathrm{z}$ „doświadczenia życia za granicą", a pozostałe 8 (4,1\% ogółu odpowiedzi) należy do wspomnianego wcześniej zbioru, wskazującego, że jest to „dobre miejsce startu w dorosłe życie".

- „Praktyczna” atrakcyjność Polski

Zbiór ten jest reprezentowany przez dwa typy wypowiedzi. Pierwszy, ujawniony 15 razy (8,9\% wszystkich odpowiedzi), skupia się na „dobrej” bądź „przystępnej” cenie studiów (koszt czesnego) lub relatywnie (w odniesieniu do innych krajów europejskich, ale nie Ukrainy) niższych kosztów utrzymania. Ponadto troje respondentów jako ważny powód decyzji podaje „brak egzaminu wstępnego" jako warunku rozpoczęcia studiów. Dodać należy, że ten typ argumentacji pojawia się także w pozostałych kontekstach lokalizacji studiów.

Decyzja o studiowaniu w Krakowie

- Uroda i atrakcyjność miasta

Kraków jest dla respondentów miastem atrakcyjnym i lubianym. Decydują o tym niemal te same kryteria, które wprowadziły centrum miasta na listę światowego dziedzictwa UNESCO, czyli kultura, architektura i historia. To dzięki nim w 40 wypowiedziach (35,7\% wszystkich odpowiedzi) ankietowani uznali miasto za piękne, ciekawe i atrakcyjne na tyle, by związać się z nim na okres studiów. Ponadto miasto w oczach studentów z Ukrainy łączy historyczną tradycję z młodością, dynamiką i potencjałem rozwoju, co pozwala optymistycznie patrzeć w przyszłość („miasto studentów”, „młode miasto”, "rozwija się", „miasto możliwości”) - znajduje to wyraz w 18 opiniach $(16,1 \%)$. Jeżeli do tej grupy wypowiedzi dodamy motyw jednocześnie najbardziej spontaniczny oraz autoteliczny, wyrażony przez 14 badanych $(12,5 \%)$ w prostym stwierdzeniu „podoba mi się”, to suma argumentów za wyborem Krakowa ze względu na atrakcyjny charakter miasta rośnie do 72 , a proporcja w stosunku do ogółu - do $64,3 \%$.

- „Bliskość” Krakowa

Na drugim miejscu pojawia się grupa motywów wynikających z poczucia obiektywnej lub subiektywnej bliskości Krakowa dla respondenta. Lokują się tu zarówno odległość od domu rodzinnego, jak i obecność w Krakowie znajomych, kolegów lub członków rodziny, a także wcześniejszy bezpośredni kontakt z miastem. W sumie ten typ argumentów odnajdujemy w 24 wskazaniach, odpowiadających proporcji równej 21,4\% ogółu. 
- „Tu mieści się KAAFM”

Z pewnym zaskoczeniem, ale też z satysfakcją zanotowałem, że o wyborze Krakowa jako miasta studiów zadecydowała lokalizacja Krakowskiej Akademii im. Andrzeja Frycza Modrzewskiego. To nie dlatego wybrano KAAFM, że znajduje się ona w Krakowie, ale odwrotnie - Kraków dlatego, że „tu mieści się KAAFM". Argument ten pojawił się 15 razy, czyli stanowi 13,4\% odpowiedzi. Nie podejmuję się jednak próby odpowiedzi czy spekulacji na temat uzasadnienia tego faktu i ograniczam się wyłącznie do jego zakomunikowania.

- Argument osobny bez komentarza

W ten sam sposób przekazuję informację, że jeden respondent wybrał Kraków dlatego, że "nie lubi Warszawy”.

Decyzja o studiowaniu w KAAFM

Na pytania ankiety służącej zebraniu danych, z których korzystam, pisząc to opracowanie, odpowiadali studenci naszej akademii, a więc osoby, które dokonały już pozytywnego jej wyboru jako miejsca swych studiów na podstawie oceny różnorodnych informacji czerpanych ze źródeł opisanych w części II. Zbudowali z nich obraz miejsca, infrastruktury, programu, wykładowców, atmosfery i wielu innych czynników decydujących o wyborze Frycza Modrzewskiego, a nie innej - zagranicznej, polskiej czy krakowskiej uczelni. Na ocenę tego obrazu, malowanego odpowiedziami na pytania ankiety, wpływają takie kryteria, jak jakość i cena studiów, opinie innych połączone z osobistymi wrażeniami, wcześniejsze doświadczenia i obecność znajomych, względna łatwość studiowania, porównanie do innych ofert i kilka takich, które nie mieszczą się w proponowanej kategoryzacji. Pamiętajmy jednak, że w badanym zbiorze znaleźli się studenci, którzy mają już co najmniej siedmiomiesięczne doświadczenie nauki w KAAFM (68 studentów I roku), a w przypadku najstarszych - blisko trzyletnie (9 studentów III roku). To powoduje, że początkowa ocena uczelni w różnym stopniu, ale we wszystkich przypadkach, została już zweryfikowana przez osobiste doświadczenia respondentów. Pamiętając o ostatniej uwadze, przyjrzyjmy się analizie typów motywacji decydującej o wyborze uczelni, uszeregowanych według malejącej częstości wyborów.

- Jakość studiów

Na czele listy znajduje się „jakość studiów”, określana odpowiedziami znajdującymi się na liście pod numerami 2 (liczba i różnorodność kierunków 
i specjalności, możliwości wyboru, ciekawy profil studiów), 3 (dobra infrastruktura akademii), 5 (dobrzy, kompetentni i przyjaźni wykładowcy), 6 (wysoki poziom nauczania), 9 (nowoczesna uczelnia) oraz 10 (nieco bardziej specyficzna kategoria: oferta studiów w języku angielskim). Wszystkie te oceny sumują się do 73 , co stanowi $50 \%$ ogółu odpowiedzi ( $\mathrm{N}$ dla odpowiedzi na to pytanie równa się 146).

- Korzystna cena

Ten rodzaj odpowiedzi, formułowany w kategoriach bezwzględnych, np. „dostępna cena”, „niedrogie studia”, lub względnych, np. „taniej niż [gdzie indziej]"11, wybrało 27 badanych (18,5\%). Na liście jednoznacznych i niezagregowanych kategorii wyboru znajduje się on pod numerem $1 \mathrm{i}$ jest najczęściej przytaczanym argumentem za wyborem uczelni. Warto jednak dodać, że pod numerem 2 z liczbą wskazań mniejszą zaledwie o jedno (26 wskazań) mieści się „liczba i różnorodność kierunków i specjalności, możliwości wyboru, ciekawy profil studiów".

- Pozytywne opinie innych korespondujące z własnymi wrażeniami

W tej kategorii kluczowe znaczenie ma słowo „opinia”, chociaż jej źródła różnią się od siebie. Na 20 uzyskanych tu odpowiedzi $(13,7 \%)$ składa się 13 typu „podoba mi się” oraz nieodniesione do nikogo albo jedynie do „uogólnionego innego" przekonanie o „dobrej reputacji” wyrażone przez 7 respondentów.

- Wcześniejsze doświadczenia i obecność znajomych

Na wcześniejszy kontakt z uczelnią oraz zadzierzgnięte tam przyjaźnie lub znajomości, a także obecność licznej grupy rodaków jako motyw wyboru szkoły wskazało razem 16 studentów (11\%). Dla porównania zauważmy, że znajomych studiujących w KAAFM jako źródło informacji o uczelni na plan pierwszy wysunęło 31 osób.

- Inne

Do tego zbioru zaliczyłem 10 odpowiedzi, w tym 4 wskazywały na brak egzaminu wstępnego i względną „łatwość zaliczania przedmiotów”, 3 respondentów uznało, że oferta KAAFM była najlepsza spośród sprawdzanych propozycji, w 2 odpowiedziach jako powód podawano to, że do zapisania

\footnotetext{
${ }^{11} \mathrm{~W}$ tym miejscu niekiedy wstawiano nazwę innej uczelni.
} 
się na uczelnię niepotrzebna była Karta Polaka ${ }^{12}$, a w 1 odpowiedzi przyznano, że o wyborze zadecydował przypadek.

\section{ROZUMIENIE JĘZYKA POLSKIEGO}

Kandydaci na studia w KAAFM, którzy mają świadectwo dojrzałości uzyskane w kraju innym niż Polska, zobowiązani są do posiadania certyfikatu znajomości języka wykładowego (uczelnia oferuje studia w języku polskim lub angielskim) na minimalnym poziomie B2 według przyjętego przez Radę Europy Europejskiego System Opisu Kształcenia Językowego. Jeżeli nie posiadają certyfikatu, mogą zostać przyjęci na studia na podstawie pozytywnego wyniku egzaminu wstępnego (na studia w języku angielskim) lub egzaminu certyfikującego Krakowskiego Towarzystwa Edukacyjnego (na studia w języku polskim; egzamin spełnia kryteria poziomu B1).

Osoba posługująca się językiem na tym [B1] poziomie rozumie znaczenie głównych wątków przekazu zawartego w jasnych, standardowych wypowiedziach, które dotyczą znanych jej spraw i zdarzeń typowych dla pracy, szkoły, czasu wolnego itd. Potrafi radzić sobie z większością sytuacji komunikacyjnych, które mogą się zdarzyć podczas podróży w rejonie, gdzie mówi się danym językiem. Potrafi tworzyć proste, spójne wypowiedzi na tematy, które są jej znane lub które ją interesują. Potrafi opisywać doświadczenia, wydarzenia, marzenia, nadzieje i aspiracje, krótko uzasadniając bądź wyjaśniając swoje opinie i plany ${ }^{13}$.

Bezpośrednie kontakty ze studentami, zwłaszcza na początku I roku, pokazują, że ten formalnie stwierdzony stan zaawansowania językowego w wielu przypadkach nie odzwierciedla rzeczywiście posiadanych umiejętności. By odnieść się do tego spostrzeżenia, postanowiłem zadać badanym pytania o ich własną ocenę znajomości języka polskiego $\mathrm{w}$ dwóch

12 „Dokument potwierdzający przynależność do narodu polskiego, który może być przyznany osobie nieposiadającej obywatelstwa polskiego albo zezwolenia na osiedlenie się na terytorium Rzeczypospolitej Polskiej oraz deklarującej przynależność do narodu polskiego i spełniającej określone ustawą warunki", https://pl.wikipedia.org/wiki/Karta_Polaka (dostęp 30 IX 2016). Jednym z uprawnień gwarantowanych przez Kartę Polaka jest prawo „dostępu do szkół publicznych wszystkich szczebli na zasadach obowiązujących obywateli polskich" (ibidem).

${ }^{13}$ Cyt. za: https://pl.wikipedia.org/wiki/Poziom_bieg\%C5\%820\%C5\%9Bci_j\%C4\%99 zykowej (dostęp 14 X 2016). 
przekrojach czasowych: w pierwszym miesiącu studiów (pytanie 9) oraz w momencie przeprowadzenia badań (pytanie 10), co w przypadku zaczynających studia na I roku przypadało na siódmy, ósmy lub dziewiąty miesiąc ich pobytu i nauki w Polsce. Student był proszony o ocenę swojego poziomu rozumienia języka polskiego według pięciopunktowej skali (od pięciu punktów w przypadku odpowiedzi „rozumiem wszystko” do jednego punktu za wybór kategorii „miałem/mam... kłopoty ze zrozumieniem większości wypowiedzi"). Uzyskane wyniki pokazuję w tabeli 2.

Tabela 2. Autoocena poziomu rozumienia języka polskiego w pierwszym miesiącu studiów w porównaniu ze stanem $\mathrm{w}$ dniu wypełniania kwestionariusza ankiety $(\mathrm{N}=98)$

\begin{tabular}{|c|c|c|c|}
\hline \multicolumn{2}{|c|}{ W pierwszym miesiącu studiów } & \multicolumn{2}{|c|}{$\begin{array}{l}\text { W dniu przeprowadzenia badań } \\
\text { (pomiędzy } 21 \text { kwietnia a } 16 \text { maja } \\
\text { oraz } 14 \text { czerwca } 2016 \text { roku) }\end{array}$} \\
\hline Wybrana kafeteria & $\begin{array}{c}\text { Liczba } \\
\text { odpowiedzi }\end{array}$ & Wybrana kafeteria & $\begin{array}{c}\text { Liczba } \\
\text { odpowiedzi }\end{array}$ \\
\hline $\begin{array}{l}\text { Rozumiałem/rozumiałam } \\
\text { wszystko }\end{array}$ & 18 & Rozumiem wszystko & 55 \\
\hline $\begin{array}{l}\text { Nie wszystko dokładnie rozu- } \\
\text { miałem/rozumiałam, ale nie } \\
\text { miałem / nie miałam kłopo- } \\
\text { tów z odczytaniem ogólnego } \\
\text { sensu wypowiedzi }\end{array}$ & 38 & $\begin{array}{l}\text { Nie wszystko dokładnie rozu- } \\
\text { miem, ale nie mam kłopotów } \\
\text { z odczytaniem ogólnego sen- } \\
\text { su wypowiedzi }\end{array}$ & 34 \\
\hline $\begin{array}{l}\text { Czasem potrzebowałem/po- } \\
\text { trzebowałam pomocy innych } \\
\text { osób }\end{array}$ & 30 & $\begin{array}{l}\text { Czasem potrzebuję pomocy } \\
\text { innych osób }\end{array}$ & 5 \\
\hline $\begin{array}{l}\text { Rozumiałem/rozumiałam tylko } \\
\text { proste wypowiedzi }\end{array}$ & 5 & $\begin{array}{l}\text { Rozumiem tylko proste } \\
\text { wypowiedzi }\end{array}$ & - \\
\hline $\begin{array}{l}\text { Miałem/miałam kłopoty ze } \\
\text { zrozumieniem większości } \\
\text { wypowiedzi }\end{array}$ & 3 & $\begin{array}{l}\text { Mam kłopoty ze zrozumie- } \\
\text { niem większości wypowiedzi }\end{array}$ & - \\
\hline Brak odpowiedzi & 4 & Brak odpowiedzi & 4 \\
\hline
\end{tabular}

Nie wnikając w rzeczywiste kompetencje językowe respondentów, dostrzegamy, że w ciągu 7 do 9 miesięcy bardzo wyraźnie wzrosła liczba studentów wysoko oceniających swoje umiejętności językowe. Zbiór 
„rozumiejących wszystko" powiększył się z 18 studentów w pierwszym miesiącu nauki do $55 \mathrm{w}$ dniu przeprowadzenia badań, a zbiór „potrzebujących pomocy innych osób" skurczył się z 30 do 5, przy czym wszyscy z tej piątki, jak pokazują dane $z$ tabeli 3, studiowali na I roku. Po 7 miesiącach nauki w Polsce żaden z respondentów nie zaliczył siebie do dwóch dolnych kategorii. Gdy uwzględni się, że wśród respondentów około 10 osób wybrało studia w języku angielskim, wynik ten pokazuje, że dla studentów z Ukrainy język polski (w mowie) nie stanowi bariery komunikacyjnej. Obserwacje prowadzone podczas pracy z tymi studentami ujawniają, że gorzej wygląda kwestia umiejętności pisania po polsku. Z braku danych potwierdzonych badaniami empirycznymi temat ten nie będzie jednak dalej rozwijany.

Jako uzupełnienie opisu stopnia rozumienia języka polskiego w samoocenie studentów należy traktować tabelę 3, pokazującą zależność tej oceny od roku studiów.

Tabela 3. Rok studiów a autoocena poziomu rozumienia języka polskiego w dniu wypełniania kwestionariusza ankiety $(\mathrm{N}=96)$

\begin{tabular}{|l|c|c|c|}
\hline \multirow{2}{*}{\multicolumn{1}{|c|}{ Autoocena }} & \multicolumn{2}{c|}{ Rok studiów (wszystkie lata: N = 96) } \\
\cline { 2 - 4 } & $\begin{array}{c}\text { I } \\
\mathrm{N}=71\end{array}$ & $\begin{array}{c}\text { II } \\
\mathrm{N}=16\end{array}$ & $\begin{array}{c}\text { III } \\
\mathrm{N}=9\end{array}$ \\
\hline Rozumiem wszystko & $35(49,2 \%)$ & $12(75 \%)$ & $7(78 \%)$ \\
\hline $\begin{array}{l}\text { Nie wszystko dokładnie rozumiem, } \\
\text { ale nie mam kłopotów z odczytaniem } \\
\text { ogólnego sensu wypowiedzi }\end{array}$ & $29(40,8 \%)$ & $4(25 \%)$ & $2(22 \%)$ \\
\hline Czasem potrzebuję pomocy innych osób & $7(9,9 \%)$ & - & - \\
\hline $\begin{array}{l}\text { Suma odpowiedzi na oba pytania } \\
\text { (autoocena i semestr/rok studiów) }\end{array}$ & 71 & 16 & 9 \\
\hline $\begin{array}{l}\text { Brak odpowiedzi na pytanie o semestr/ } \\
\text { rok studiów }\end{array}$ & \multicolumn{2}{|l}{} \\
\hline
\end{tabular}

Podkreślam w tym miejscu, że w próbie badawczej 71 studentów (74\%) było na roku I, $16(16,7 \%)$ na roku II oraz $9(9,4 \%)$ na III roku studiów (razem: 96). W sumie na to pytanie odpowiedziało 96 osób, co oznacza, że w dwóch przypadkach respondenci tego nie zrobili. Wyniki przedstawione $w$ tabeli 3 układają się we wzór dość oczywisty: poziom samooceny rozumienia języka polskiego przez studentów rośnie wraz z wydłużaniem się czasu studiowania. 


\section{KONTAKTY Z POLAKAMI}

Zakładamy, że postęp w zakresie sprawności posługiwania się językiem polskim wynika z upływu czasu pobytu studentów w Polsce, obowiązku uczestniczenia w kursach języka polskiego organizowanych przez uczel$n_{1} e^{14}$, ale przede wszystkim z częstotliwości i intensywności rozmów w języku polskim. Kontakty z Polakami w języku polskim odbywają się w obrębie dwóch obszarów: formalnego (na uczelni - głównie w procesie dydaktycznym, a także dla niektórych w miejscu pracy) oraz nieformalnego (w sferze prywatnej). Za wskaźnik częstotliwości/intensywności rozmów po polsku uznałem odpowiedź na pytanie o to, jak wiele czasu w skali dnia zajmują badanym rozmowy $w$ tym języku. $W$ świetle tych subiektywnych szacunków zawartych w 96 odpowiedziach ( $\mathrm{N}=96)$ :

- przez większość dnia rozmawiało 7 respondentów,

- często - 24,

- mniej więcej w połowie rozmów języka polskiego używały 34 osoby,

- przez mniejszą część dnia rozmawiało w tym języku 17 osób,

- od czasu do czasu - 14.

Okazuje się, że ekspozycja studentów polskiej uczelni mieszkających w Polsce na kontakty w języku polskim nie jest szczególnie wysoka. Oceniają oni, że około $2 / 3$ rozmów odbytych w ciągu dnia przebiega w języku polskim, ale jednak $1 / 3$ badanych rozmawia po polsku rzadko lub wręcz sporadycznie. Oznacza to, że przez większość czasu przebywają oni w kręgu rozmówców swojego języka rodzimego. Potwierdzenie tego przypuszczenia znajdujemy w rozkładzie 96 odpowiedzi przy pytaniu 11 o to, skąd pochodzą osoby, z którymi badani codziennie rozmawiają. Rozkład ten przedstawia się następująco ( $\mathrm{N}=96)$ :

- wyłącznie z kraju mojego pochodzenia - 18,

- w większości z kraju mojego pochodzenia - 42,

- w połowie z kraju mojego pochodzenia - 28,

- w mniejszości z kraju mojego pochodzenia - 7,

- rzadko z kraju mojego pochodzenia - 1.

${ }^{14} \mathrm{Na}$ podstawie Zarządzenia Rektora Krakowskiej Akademii im. Andrzeja Frycza Modrzewskiego nr 16/2014 z 5 maja 2014 roku uczelnia wprowadziła 120-godzinny obowiązkowy kurs języka polskiego dla cudzoziemców rozpoczynających studia w języku polskim. Zob. http://www.ka.edu.pl/gfx/ksw/userfiles/rekrutacja/2014_2015/zarzadzenie_r.__kursy_j._polskiego_dla_cudzoziemcow.pdf (dostęp 4 X 2016). 
W ujęciu proporcjonalnym struktura pochodzenia, a w zasadzie obywatelstwa codziennych rozmówców, a co za tym idzie - bezpośrednich kontaktów badanych studentów - staje się wyraźniejsza od oglądu ich liczebności. Niemal 90\% (dokładnie 89,4\%) badanych deklaruje, że połowa i więcej ich wszystkich codziennych rozmów toczy się w grupie osób wywodzących się z państwa ich pochodzenia ${ }^{15}$, a jedynie około $10 \%$ - że rozmowy odbywają się poza tym kręgiem. Nie chcę posługiwać się tu terminem "gettoizacja”, obarczonym pejoratywnymi skojarzeniami, ale uzyskane wyniki świadczą o wysokim poziomie izolacji tej zbiorowości i jej jeszcze słabej podatności na procesy integracyjne. Jedną z przyczyn tego stanu może być relatywnie krótki okres studiowania w Polsce (74\% respondentów w czasie przeprowadzenia badań studiowało na I roku). Przyjrzyjmy się więc ponownie danym dotyczącym pochodzenia codziennych rozmówców respondentów oraz częstotliwości i intensywności rozmów w języku polskim w kontekście roku studiów, przy czym osobnymi kategoriami porównawczymi będą studenci I roku studiów oraz zagregowany zbiór studiujących na II i III roku.

Tabela 4. Rok studiów a struktura pochodzenia codziennych rozmówców respondentów ${ }^{16}(\mathrm{~N}=96)$

\begin{tabular}{|l|c|c|c|c|}
\hline \multirow{2}{*}{$\begin{array}{c}\text { Kategorie pochodzenia codziennych rozmówców } \\
\text { respondentów }\end{array}$} & \multicolumn{3}{|c|}{ Rok studiów (N = 96) } \\
\cline { 2 - 5 } & $\begin{array}{c}\text { Liczba } \\
\text { (N = 71) }\end{array}$ & $\%$ & $\begin{array}{c}\text { Liczba } \\
\text { (N = 25) }\end{array}$ & $\%$ \\
\hline Wyłącznie z kraju mojego pochodzenia (z Ukrainy) & 15 & 21 & 3 & 12 \\
\hline W większości z kraju mojego pochodzenia & 31 & 44 & 11 & 44 \\
\hline W połowie z kraju mojego pochodzenia & 21 & 30 & 7 & 28 \\
\hline W mniejszości z kraju mojego pochodzenia & 4 & 5 & 3 & 12 \\
\hline Rzadko z kraju mojego pochodzenia & 0 & 0 & 1 & 4 \\
\hline
\end{tabular}

${ }^{15}$ Próba badawcza obejmowała obywateli Ukrainy. Jej wewnętrzne podziały językowe, religijne czy - szerzej - etniczne nie wchodziły w zakres problemu badawczego.

${ }^{16} \mathrm{~W}$ ankiecie umieszczono pytanie następującej treści: „Osoby, z którymi codziennie rozmawiam, pochodzą:". Pod tym zdaniem zamieszczone były kategorie wyboru zacytowane $w$ tabeli 4. 
Pomimo że przedstawione w procentach proporcje, zwłaszcza z powodu niskiej liczebności respondentów z II i III roku studiów, nie mają istotnego znaczenia w rozumieniu statystyki, to jednak prowokują do zadania pytania o to, czy dłuższy czas studiowania rzeczywiście prowadzi do zmiany środowiska codziennych kontaktów studentów z Ukrainy, a w konsekwencji do ich głębszej integracji ze środowiskiem studentów polskich, czy też izolacja w obrębie zbiorowości własnego kraju pozostaje cechą trwałą. W szerszym kontekście pytanie to dotyczy oczywiście także innych studentów obcokrajowców. Dane uzyskane w naszych badaniach mają widoczne „spłaszczenie" wartości skrajnych na wyższych latach studiów, ale nie uprawniają do odpowiedzialnego przyjęcia tu jednoznacznej odpowiedzi, zwłaszcza w sytuacji, gdzie pojedyncza odpowiedź ma wartość 4 punktów procentowych. Gdyby jednak wspomniane „spłaszczenie” wartości skrajnych (relatywny spadek proporcji rozmówców pochodzących wyłącznie z kraju pochodzenia respondenta oraz relatywne zwiększenie proporcji odpowiedzi stwierdzających, że rozmówcy rzadko pochodzą z tego samego kraju) interpretować jako skutek dłuższego przebywania studentów lat wyższych w Polsce i jako pojawienie się symptomów integracyjnych, to utrzymywanie się na podobnym poziomie proporcji odpowiedzi na pytania ze środka skali wskazywałoby na bardzo wyraźne ograniczenie tych symptomów. Dla uzyskania wiarygodniejszej odpowiedzi konieczne jest przeprowadzenie badań na znacznie większej i bardziej zrównoważonej próbie respondentów.

By dopełnić obraz wpływu długości czasu studiowania na procesy integracji studentów z Ukrainy ze społeczeństwem polskim, przyjrzyjmy się temu, czy rok studiów zmienia częstotliwość posługiwania się językiem polskim. Dane te przedstawiam w tabeli 5.

Zaprezentowany rozkład dość wyraźnie pokazuje bardzo interesującą tendencję. Pomimo że na roku II i III w porównaniu z rokiem I krąg codziennych rozmówców naszych respondentów zmienia się w bardzo niewielkim stopniu i wciąż większość czasu spędzają oni w gronie swoich rodaków, to jednak wyraźnie częściej posługują się językiem polskim. Przez większość dnia po polsku rozmawia $12 \%$ studentów II i III roku w porównaniu z niecałymi $6 \%$ na roku I. Proporcja wybierających pozostałe kategorie odpowiedzi (z wyjątkiem kategorii „mniej więcej w połowie”, na którą wskazuje niemal taka sama liczba badanych z roku I, jak i II łącznie z III) również wskazuje na zwiększenie się proporcji czasu poświęcanego na rozmowy po polsku. Konstatację tę należy jednak traktować bardzo ostrożnie, ponieważ nie ma ona wystarczającej podstawy statystycznej. Powtórzmy więc, że 
nieproporcjonalnie mała liczba studentów II i III roku w stosunku do roku I (w proporcji bliskiej $1 / 4$ ) nie upoważnia do tworzenia szerszych analiz wpływu roku studiów na wzrost kompetencji językowych czy fluktuacje innych zmiennych, pozostawiając odpowiedzi na wiele stawianych tu pytań przyszłym studiom empirycznym.

Tabela 5. Rok studiów a proporcja czasu posługiwania się językiem polskim w ciągu dnia ${ }^{17}(\mathrm{~N}=96)$

\begin{tabular}{|l|c|c|c|c|c|c|}
\hline \multirow{2}{*}{\begin{tabular}{c} 
Proporcja czasu posługiwania \\
się językiem polskim w ciągu \\
\cline { 2 - 7 } \\
\cline { 2 - 7 }
\end{tabular}} & \multicolumn{2}{|c|}{ Inia } \\
\cline { 2 - 7 } & $\begin{array}{c}\text { Liczba } \\
(\mathrm{N}=71)\end{array}$ & $\%$ & $\begin{array}{c}\text { Liczba } \\
(\mathrm{N}=25)\end{array}$ & $\%$ & $\begin{array}{c}\text { Liczba } \\
(\mathrm{N}=96)\end{array}$ & $\%$ \\
\hline Przez większość dnia & 4 & 6 & 3 & 12 & 7 & 7 \\
\hline Często & 14 & 20 & 10 & 40 & 24 & 25 \\
\hline $\begin{array}{l}\text { Mniej więcej w połowie moich } \\
\text { rozmów }\end{array}$ & 25 & 35 & 9 & 36 & 34 & 35 \\
\hline Przez mniejszą część dnia & 16 & 22 & 1 & 4 & 17 & 18 \\
\hline Od czasu do czasu & 12 & 17 & 2 & 8 & 14 & 14 \\
\hline
\end{tabular}

Wiele klasycznych teorii asymilacji, począwszy od koncepcji Miltona M. Gordona ${ }^{18}$, posługuje się pojęciem asymilacji strukturalnej, która traktowana jest jako rodzaj progu akceptacji imigranta jako członka społeczeństwa przyjmującego. Symbolicznymi, ale i realnymi wyznacznikami tej akceptacji są, zgodnie z tradycją Maxa Webera, dwa kryteria: connubium ${ }^{19}$, które najprościej mówiąc - oznacza społeczną akceptację dla małżeństw mieszanych, oraz komensalizm, w interesującym nas przypadku oznaczający

${ }^{17}$ W ankiecie użyto stwierdzenia: „Po polsku rozmawiam:”, które respondent miał dokończyć poprzez wybór jednej z pięciu kategorii zacytowanych w tabeli 5.

${ }^{18}$ Koncepcja po raz pierwszy została opisana w: M.M. Gordon, Assimilation in American Life. The Role of Race, Religion, and National Origins, New York 1964.

${ }^{19}$ Pojęcie connubium w studiach nad etnicznością określa finalne stadium asymilacji, czyli amalgamację, co oznacza integrację pomiędzy grupami etnicznymi (a także rasowymi i narodowymi) w wyniku zawierania małżeństw przez osoby należące do odmiennych kategorii grupowych. 
współbiesiadnictwo (wspólne spożywanie posiłków) podejmowane przez ludzi zaliczanych do odrębnych kategorii społecznych (klasowych, rasowych, etnicznych, narodowościowych, płci, wieku itp.). Podobną rolę odgrywa przyjmowanie "obcego" we własnym domu lub wizyta u niego. By uchwycić w omawianych badaniach rolę tego kryterium, zamieściłem w ankiecie dwa powiązane ze sobą pytania - pytanie 15 o treści: „Czy odwiedza Pan/Pani Polaków w ich miejscu zamieszkania?”, oraz pytanie 16: "Czy Polacy odwiedzają Pana/Panią w Pana/Pani miejscu zamieszkania?". Rozkład odpowiedzi w całej próbie badawczej przedstawiam w tabeli 6 .

Tabela 6. Wzajemne odwiedziny Polaków i Ukraińców w ich miejscach zamieszkania

\begin{tabular}{|l|c|c|}
\hline \multicolumn{1}{|c|}{ Kategoria odpowiedzi } & $\begin{array}{c}\text { Odwiedziny respondenta } \\
\text { w miejscu zamieszania } \\
\text { Polaków (N = 98) }\end{array}$ & $\begin{array}{c}\text { Odwiedziny Polaków } \\
\text { w miejscu zamieszkania } \\
\text { respondenta (N = 98) }\end{array}$ \\
\hline Tak, często & 8 & 8 \\
\hline Tak, czasami & 17 & 16 \\
\hline $\begin{array}{l}\text { Tak, odwiedziłem/odwiedziłam } \\
\text { jedną osobę lub dwie }\end{array}$ & 12 & 9 \\
\hline $\begin{array}{l}\text { Spotykam się z Polakami, ale nie } \\
\text { w ich/moim miejscu zamieszkania }\end{array}$ & 38 & 19 \\
\hline $\begin{array}{l}\text { Rzadko mam bliższe kontakty } \\
\text { z Polakami }\end{array}$ & 19 & 6 \\
\hline Brak odpowiedzi & 4 & 40 \\
\hline
\end{tabular}

Otrzymane wyniki pokazują, że nasi studenci z Ukrainy najczęściej spotykają się z Polakami poza miejscami, w których mieszkają i jedni, i drudzy, co w odpowiedziach na oba pytania zaznaczyło około odpowiednio 38 i 40 respondentów. Żałuję, że nie zapytałem o to, gdzie konkretnie się spotykają (na uczelni, na Rynku Głównym, w piwiarni itp.), a także o charakter tych spotkań (umówione, intencjonalne, przypadkowe - bo przecież spotykanie Polaków w Polsce jest oczywiste, chociaż nie nieuchronne). Ale żal ten ma swoją dobrą stronę, bo wynika z potencjału tych pytań, co prawda ujawnionego dopiero na etapie analizy i dlatego niewykorzystanego. Daje jednak doświadczenie pozwalające nadrobić braki w następnych, bardziej pogłębionych studiach. 
Jeśli chodzi o skrajne wartości częstotliwości odwiedzin: częstszych od średniej i rzadszych od średniej, to po wyłączeniu z analizy spotkań poza miejscem zamieszkania okazuje się, że duża izolacja studentów z Ukrainy w Krakowie raczej nam nie grozi. W sumie 37 respondentów przynajmniej raz odwiedziło jakiegoś Polaka w jego miejscu zamieszkania, a 33 przyjęło go u siebie. Optymizm w ocenie tych danych wynika jednak raczej z przeciwstawienia ich tym, które wskazują na brak takich odwiedzin, bo na rzadkie kontakty z Polakami w odpowiedzi na oba pytania wskazało po 19 osób, a jeśli brak odpowiedzi traktować jako wyraz obawy przed przyznaniem się do braku bliższych kontaktów, to te sumy rosną odpowiednio do 23 osób w przypadku odwiedzin u Polaków i 25 w przypadku pełnienia roli gospodarza takiej wizyty. Ponadto trzeba pamiętać, że $74 \%$ naszych respondentów w momencie wypełniania kwestionariusza ankiety było dopiero na I roku studiów. Równocześnie jednak około $1 / 4$ do 1/5 studentów praktycznie nie ma bliskich kontaktów z Polakami, co ten wstępny optymizm „integracyjny" w znacznym stopniu studzi.

\section{PRZYKRE DOŚWIADCZENIA ZWIĄZANE Z POCHODZENIEM NARODOWYM STUDENTÓW}

W badanej zbiorowości 22 respondentów potwierdziło, że doświadczyli przykrego traktowania w związku ze swym pochodzeniem narodowym, a 76 osób z takimi sytuacjami bezpośrednio się nie zetknęło. W ośmiu przypadkach doświadczenia te miały miejsce na terenie KAAFM, w kilku na terenie miasta. Najczęściej studenci skarżą się na brak szacunku dla ich kraju i kultury („Nie ma powagi dla obcokrajowców”), relacjonują przypadki niesprawiedliwych ocen („Dostaliśmy z kolegami 4,5, kiedy test był napisany poprawnie i było od razu powiedziane, iż nie jesteśmy Polakami, by znać ten przedmiot na $\left.5^{\prime \prime}\right)$, skarżą się na odrzucanie przez studentów Polaków inicjatywy lepszego poznania się („W pierwszym miesiącu u nas nie było integracji z Polakami z naszego roku i to czasami oni mówili, żeby my nawet nie przyjeżdżali, bo i tak jest nas za dużo. Przykro to było słuchać”; „Było tak, że chciałam zapoznać się z Polkami, a one nie"), a nawet na zachowania jawnie nacjonalistyczne („Na zajęciach nie pogodziliśmy się ze studentami z Polski. Oni krzyczeli »Polska dla Polaków«"). Jeden z respondentów cytuje wulgarną uwagę, którą przypisuje wykładowcy: „O kurde, to tie pojebane Ukraińcy". 
Inna konkretna sytuacja została opisana w sposób następujący:

Kiedy miałem ćwiczenia z języka polskiego, Pani [...] bardzo często mówiła o tym, że kiedy jadę do tego kraju obcego na studia, to muszę świetnie rozmawiać w tym języku. Jej głównym celem było nauczyć języka, a nie brzydkimi zdaniami mówić w stronę studentów.

Być może w tym akurat przypadku intencja nauczyciela została zrozumiana opacznie, ale ogólne uwagi na temat „narzekania” przez profesorów na Ukrainę, "traktowania stereotypowego Ukraińców oraz niemiłej postawy niektórych wykładowców" pojawiają się w wypełnionych kwestionariuszach znacznie częściej.

Na terenie miasta studenci doświadczyli odmowy obsługi w jednej z kawiarni w centrum Krakowa, czasami wulgarnych wyzwisk na ulicy czy odrzucenia na rynku pracy, co ilustruje następująca wypowiedź: „Kiedy szukałam pracę i telefonowałam w sprawie pracy, to mi mówiły: "Pani jest z Ukrainy, do widzenia «". Jeden z respondentów, nie opisując w szczegółach nieprzyjemnych zdarzeń, jakich doświadczył, w odpowiedzi na pytanie ankiety ujmuje to następująco: „Dlatego, że jestem Ukraińcem, niektóre Polacy myślą, że jestem z UPA i morduję Polaków". Widać więc, że jest on w pełni świadomy obecności negatywnego stereotypu Ukraińca w społeczeństwie polskim. W dwóch przypadkach respondenci potwierdzili wystąpienie przykrej sytuacji, ale odmówili podania bliższego opisu, kwitując sprawę prostym „nie powiem” lub "nie chcę o tym mówić".

Drugie pytanie $w$ tej czteroelementowej sekwencji dotyczyło przykrych doświadczeń innych osób, które respondent zaobserwował lub o których słyszał. Rozkład odpowiedzi na pytanie "Czy kiedykolwiek w czasie Pana/ Pani studiów był Pan / była Pani świadkiem doświadczenia przykrej sytuacji przez inną osobę z powodu pochodzenia narodowego" przedstawia się następująco: (A) TAK - 11 odpowiedzi, (B) NIE - 42 odpowiedzi, (C) słyszałem/ słyszałam o takich sytuacjach od innych osób - 39 (razem: 92 odpowiedzi). W tym jednak przypadku z wyjątkiem opisu zajścia na Rynku Głównym, gdzie Ukraińców obrzucono wyzwiskami, wzmianki o zdarzeniach dyskryminacyjnych mają charakter ogólny i niekonkretny, np. „Nie wszystkie Polaki dobre na stosunki ${ }^{20}$ do Ukrainy" czy "Jeden z poważnych profesorów

${ }^{20}$ Ma to oznaczać, że nie wszyscy Polacy mają pozytywny stosunek do Ukrainy. 
traktował Ukraińców luźniej ${ }^{21}$ od innych” bądź przekonanie, że „Było tak, że osobom z Polski [wykładowcy] stawiali wyższą ocenę".

\section{OCENA DECYZJI STUDIOWANIA W KAAFM}

Po analizie źródeł informacji na temat studiowania w KAAFM, motywów podjęcia tej decyzji i doświadczeń pierwszego semestru, a w sumie co najmniej 7 miesięcy pobytu w Polsce, Krakowie i w Krakowskiej Akademii im. Andrzeja Frycza Modrzewskiego, przychodzi czas na zapoznanie się z ogólną oceną takiej decyzji przez studentów. Rozkład odpowiedzi na pytanie o tę ocenę przedstawia się następująco:

1. Bardzo dobra decyzja - 11

2. Dobra decyzja - 49

3. Ani dobra, ani zła -32

4. Zła -1

5. Bardzo zła -1

Ogółem - 94 odpowiedzi

Brak odpowiedzi - 3

W sumie wyraźna większość studentów (60 odpowiedzi) uznała swą decyzję za dobrą lub nawet bardzo dobrą, a jedynie dwie osoby za złą i bardzo złą. Można przy tym wyniku popaść w samozadowolenie. By tego nie zrobić, należy przyjrzeć się bardziej szczegółowym ocenom rozmaitych elementów tej opinii. W tym miejscu trzeba przypomnieć, że seria odpowiedzi jest tu zindeksowanym i zagregowanym obrazem swobodnych, indywidualnych opinii, będących reakcjami na pytania otwarte, a więc nieobarczone gotowymi kafeteriami, mogącymi sugerować choćby kategorie czy kryteria mające ukierunkować sposób postrzegania różnych aspektów funkcjonowania akademii (dydaktyki, infrastruktury, atmosfery itp.). Kolejne dwie tabele pokazują - w podziale na pozytywne i negatywne - różne zespoły zdarzeń lub cech ocenianych przez studentów.

Interpretację tabeli 7 trzeba zacząć od ostatniej rubryki - „ogółem”. Są tu podane całkowite liczby opinii napisanych przez studentów w kwestionariuszach ankiet w podziale na „pozytywne” $i$ „negatywne”. W sumie

${ }^{21}$ Miało to oznaczać brak należnego szacunku. Tak tłumaczyli mi intencję respondenta jego ukraińscy koledzy. 
Tabela 7. Dlaczego decyzję o studiowaniu w KAAFM oceniono jako dobrą lub złą ( $N=98)$

\begin{tabular}{|c|c|c|c|}
\hline \multicolumn{2}{|l|}{ Oceny pozytywne, plusy } & \multicolumn{2}{|l|}{ Oceny negatywne, minusy } \\
\hline Treść oceny & $\begin{array}{c}\text { Ilość } \\
\text { wskazań }\end{array}$ & Treść oceny & $\begin{array}{c}\text { Ilość } \\
\text { wskazań }\end{array}$ \\
\hline $\begin{array}{l}\text { Postawa nauczycieli wobec stu- } \\
\text { dentów, tolerancja, poszanowa- } \\
\text { nie tradycji }{ }^{22}\end{array}$ & 15 & $\begin{array}{l}\text { Niskie kwalifikacje niektórych } \\
\text { nauczycieli, ich małe zaintere- } \\
\text { sowanie dydaktyką, pasywność, } \\
\text { schematyzm, nudne zajęcia, złe } \\
\text { traktowanie studentów, „brak } \\
\text { szacunku dla Ukraińców” }\end{array}$ & 15 \\
\hline Wysoki poziom nauczania & 13 & $\begin{array}{l}\text { Za mało zajęć (w tym z języków } \\
\text { obcych), „brakuje zadań domo- } \\
\text { wych”, „zbyt łatwe studiowanie” }\end{array}$ & 12 \\
\hline $\begin{array}{l}\text { Podoba mi się. Jestem } \\
\text { zadowolony/zadowolona }\end{array}$ & 11 & Zbyt dużo studentów z Ukrainy & 9 \\
\hline $\begin{array}{l}\text { Nowocześnie prowadzone, do- } \\
\text { brze zorganizowane zajęcia }\end{array}$ & 8 & $\begin{array}{l}\text { Zła organizacja zajęć, niedogod- } \\
\text { ny harmonogram }\end{array}$ & 9 \\
\hline $\begin{array}{l}\text { Nowy etap w życiu, dobry start, } \\
\text { nowe doświadczenia }\end{array}$ & 8 & Zajęcia mało praktyczne & 4 \\
\hline $\begin{array}{l}\text { Dyplom europejski, możliwo- } \\
\text { ści wyjazdów zagranicznych } \\
\text { (np. program Erasmus) }\end{array}$ & 8 & „Średnio mi się podoba” & 2 \\
\hline $\begin{array}{l}\text { Wiele możliwości wyboru kie- } \\
\text { runków, specjalności }\end{array}$ & 6 & Trudno znaleźć pracę & 1 \\
\hline $\begin{array}{l}\text { „Jeśli chcesz studiować, } \\
\text { to akademia daje ci wszystko, } \\
\text { co potrzebne” }\end{array}$ & 5 & $\begin{array}{l}\text { Dyplom KAAFM nie jest } \\
\text { zbyt wysoko ceniony przez } \\
\text { pracodawców }\end{array}$ & 1 \\
\hline $\begin{array}{l}\text { Spotkanie interesujących ludzi, } \\
\text { nawiązanie przyjaźni }\end{array}$ & 3 & Nie ma targów pracy & 1 \\
\hline „Lepiej niż na Ukrainie” & 3 & & \\
\hline Łatwe zaliczanie przedmiotów & 2 & & \\
\hline Inne, pojedyncze ${ }^{23}$ & 4 & & \\
\hline Ogółem & 86 & Ogółem & 54 \\
\hline
\end{tabular}

${ }^{22} \mathrm{Na}$ przykład dni wolne od nauki w czasie ukraińskich świąt.

23 "Dobra praktyka językowa (angielski)”, "dużo studentów z Ukrainy”, "można łączyć studia i pracę". 
respondenci wyrazili 140 opinii, co oznacza, że średnio jeden respondent poddał ocenie, jeśli tak można powiedzieć, 1,43 jakiegoś zdarzenia lub cechy mających związek z procesem studiowania w KAAFM. Proporcja ocen pozytywnych do wszystkich ocen wyrażona w procentach wynosi 61,4 . Inaczej mówiąc, na dwie oceny pozytywne przypada nieco więcej niż jedna ocena negatywna.

Jeśli chodzi o treść ocen, to uderza idealnie zrównoważona rozbieżność ocen nauczycieli: 15 ocen pozytywnych i 15 negatywnych. $Z$ powodu braku wiedzy na temat konkretnych przypadków nie podejmuję się komentować tej sytuacji, zauważam jednak, że istnieje jakiś rodzaj napięcia bądź niezrozumienia pomiędzy kadrą nauczającą a studentami z Ukrainy. Wśród pozytywów na drugim miejscu znajdujemy „wysoki poziom nauczania”, wskazywany przez 13 respondentów. Po stronie negatywnej jako rodzaj przeciwwagi można traktować skargi na to, że... studia są zbyt łatwe, a studenci woleliby większą ilość zajęć, zadań domowych czy sprawdzianów24. Przeciwstawność ocen pojawia się także w związku z organizacją zajęć. Potwierdzają się wyrażane w wielu poprzednich odpowiedziach przekonania o wysokiej z punktu widzenia respondentów - wartości dyplomu akademii, uznawanego w całej Europie przede wszystkim w związku z członkostwem Polski w Unii Europejskiej. Na uwagę zasługuje również umieszczenie po stronie negatywnej stwierdzenia o zbyt dużej liczbie studentów z Ukrainy na uczelni, a właściwie o wytworzeniu przez nich własnego, wyraźnie odrębnego od reszty studentów środowiska. Właściwie każde ze zdarzeń i cech ocenianych przez studentów zasługuje na szczegółową analizę. Nie jest to jednak możliwe na podstawie danych empirycznych uzyskanych w niniejszych badaniach. Pozostańmy zatem przy zdrowym rozsądku pięciu respondentów, wyrażonym przez jednego z nich $\mathrm{w}$ zdaniu zacytowanym $\mathrm{w}$ tabeli: "Jeśli chcesz studiować, to akademia daje ci wszystko, co potrzebne".

Następna tabela prezentuje $z$ jednej strony rozwinięcie i uszczegółowienie, a z drugiej wyostrzenie ogólnej oceny studiowania w KAAFM. Respondentom zadałem pytania (7 i 8) o najlepiej i najgorzej ocenianą właściwość lub cechę obecnych studiów w akademii. Zagregowane wyniki zamieszczone zostały w tabeli 8.

${ }^{24}$ Być może związane jest to z odmiennością stylu czy kultury studiowania w Polsce i w Ukrainie. Ponieważ nie mam żadnych doświadczeń z ukraińskim systemem studiów wyższych, pozostawiam tę kwestię bez komentarza. 
Tabela 8. Najlepiej i najgorzej oceniane cechy studiów ( $N=98)$

\begin{tabular}{|c|c|c|c|}
\hline \multicolumn{2}{|l|}{ Oceny pozytywne, plusy } & \multicolumn{2}{|l|}{ Oceny negatywne, minusy } \\
\hline Treść oceny & $\begin{array}{c}\text { Ilość } \\
\text { wskazań }\end{array}$ & Treść oceny & $\begin{array}{c}\text { Ilość } \\
\text { wskazań }\end{array}$ \\
\hline $\begin{array}{l}\text { Wysoki poziom nauczania, ja- } \\
\text { kość studiów, wysoki poziom } \\
\text { profesjonalizmu wykładowców, } \\
\text { sprawna organizacja zajęć }\end{array}$ & 50 & Harmonogram, rozkład zajęć & 15 \\
\hline $\begin{array}{l}\text { Postawa nauczycieli wobec stu- } \\
\text { dentów, pomoc wykładowców, } \\
\text { dobra atmosfera na zajęciach }\end{array}$ & 16 & $\begin{array}{l}\text { Okazywana przez niektórych } \\
\text { pracowników niechęć do } \\
\text { Ukraińców }\end{array}$ & 8 \\
\hline $\begin{array}{l}\text { Nowy etap w życiu, dobry start, } \\
\text { nowe doświadczenia }\end{array}$ & 7 & $\begin{array}{l}\text { Praca dziekanatu: kolejki, brak } \\
\text { chęci udzielenia pomocy }\end{array}$ & 7 \\
\hline $\begin{array}{l}\text { Indywidualnie wymieniane na- } \\
\text { zwiska wykładowców }\end{array}$ & 6 & Niektórzy wykładowcy ${ }^{25}$ & 6 \\
\hline „Wszystko w porządku” & 6 & Za mało praktyk i ćwiczeń & 5 \\
\hline Biblioteka & 6 & Słaby poziom niektórych zajęć & 5 \\
\hline Studia dają się pogodzić z pracą & 5 & „Drogo”, „za drogo” & 4 \\
\hline Dobra atmosfera & 4 & $\begin{array}{l}\text { Za dużo niepotrzebnych } \\
\text { przedmiotów }\end{array}$ & 4 \\
\hline Harmonogram & 3 & $\begin{array}{l}\text { Słaba motywacja do pracy ze } \\
\text { strony wykładowców }\end{array}$ & 3 \\
\hline \multirow[t]{4}{*}{ Inne, pojedyncze ${ }^{26}$} & 10 & Zła praca wirtualnego dziekanatu & 2 \\
\hline & & $\begin{array}{l}\text { Słaba znajomość języka an- } \\
\text { gielskiego u niektórych } \\
\text { wykładowców }\end{array}$ & 2 \\
\hline & & Brak przyjaźni w grupie & 2 \\
\hline & & Inne, pojedyncze ${ }^{27}$ & 8 \\
\hline Ogółem & 113 & Ogółem & 71 \\
\hline
\end{tabular}

${ }^{25} \mathrm{~W}$ tym jeden wymieniony z nazwiska.

${ }^{26}$ „Sporo czasu dla siebie”, „atrakcyjna cena programu w języku angielskim”, „sala 008”, "filozofia”, „handel międzynarodowy”, „demografia”, „poczucie europejskości”, „studia nie są na Ukrainie”, „Erasmus”, „wszystko można znaleźć w internecie”.

27 "Wielokrotne powtarzanie materiału na różnych zajęciach”, „dresscode na egzaminach”, „zajęcia z historii stosunków międzynarodowych”, „światła na przejściu dla pieszych przed budynkiem szkoły (zbyt długo świeci się czerwone światło)”, „opłaty za wszystko, co możliwe, zapiekanka, egzaminy”, „brak zrozumienia sytuacji cudzoziemca”, „nie ma możliwości uzyskania stypendium rektora”, „brak studiów bliskowschodnich II stopnia”. 
Tym razem, przymuszeni nieco bezpośrednim charakterem pytania, respondenci sformułowali więcej opinii, bo 184, co na jedną osobę daje wskaźnik 1,88. Proporcja ocen pozytywnych do wszystkich ocen wynosi 62,8 , a więc $w$ zasadzie pozostaje na tym samym poziomie, co w przypadku oceny ogólnej. Zmienia się natomiast merytoryczna zawartość ocen. Generalnie $w$ większym stopniu dotyczą one praktycznych i codziennych aspektów studiowania niż w przypadku ocen z tabeli 7. Wśród zdarzeń i cech ocenianych pozytywnie na pierwsze miejsce wysuwa się najważniejszy dla akademii, bo dydaktyczny, aspekt jej działalności. Większość, 50 na 98 respondentów, ocenia go pozytywnie, a następne 16 opinii zwraca uwagę na gotowość do udzielania pomocy przez nauczycieli akademickich. Niestety, po stronie negatywnej znajdujemy opinie przeciwstawne - wskazujące na nieprzychylność niektórych pracowników naukowych dla Ukraińców. Wyjaśnia to po części charakter 15 negatywnych ocen kadry nauczającej z tabeli 7. Przynajmniej w połowie przypadków nie chodzi tu raczej o kompetencje zawodowe, ale o postawę, może niechęć, może niezrozumienie odrębności kulturowej, z przykrością odczuwane przez studentów z Ukrainy. Pozostałe negatywne oceny w większości koncentrują się na praktyce życia codziennego $w$ akademii, gdzie niezadowolenie $z$ harmonogramu zajęć czy z pracy dziekanatu zajmują pierwsze miejsca w rankingu krytyki.

\section{REZYGNACJA ZE STUDIÓW}

Spośród 98 respondentów 31 osób miało taki moment, w którym rozważały możliwość rezygnacji ze studiów, ale 67 pozostałych podobnych wahań i rozterek nie przeżywało, a przynajmniej nie zdecydowało się wspomnieć o nich w ankiecie. Rozkład głównych powodów skłaniających studentów do rezygnacji przedstawia się następująco:

- zamiar zmiany uczelni lub kierunku - 7 odpowiedzi,

- rozczarowanie zajęciami lub wykładowcami - 5 odpowiedzi,

- problemy z adaptacją w nowym środowisku - 5 odpowiedzi,

- zły system praktyk - 4 odpowiedzi,

- słabe wyniki pierwszej sesji egzaminacyjnej- 3 odpowiedzi,

- tęsknota za rodzicami lub dziewczyną - 2 odpowiedzi,

- trudności w pogodzeniu nauki z pracą - 2 odpowiedzi,

- opłata 400 zł za egzamin warunkowy-1 odpowiedź,

- inne -2 odpowiedzi.

Razem: 31 odpowiedzi. 
W ankiecie nie zamieszczono żadnych dalszych pytań mających pokazać bardziej szczegółowe uzasadnienia decyzji o ewentualnej rezygnacji ze studiów.

\section{RADY DLA KOLEGÓW}

$\mathrm{Na}$ (w pewnym sensie syntetyczne) pytanie $\mathrm{nr} 23$ - o to, czy studenci zarekomendowaliby znajomemu studiowanie w KAAFM - w sumie odpowiedziały tylko 33 osoby. Mimo że pytanie to miało niejako wieńczyć kwestionariusz, który przeglądało przed rozpowszechnieniem kilka osób, zostało ono usytuowane tak nieszczęśliwie i zarazem bez gotowych do zakreślenia kafeterii TAK i NIE, że większość respondentów mogła go zwyczajnie nie zauważyć. Ci, którzy je przeczytali i chcieli odpowiedzieć, musieli odpowiedź po prostu wpisać. Dla porządku podaję więc, że TAK odpowiedziało 18 respondentów (54,5\%), NIE - 6 (18,2\%), a innej odpowiedzi, najczęściej o charakterze warunkowym („to zależy od..." - i tutaj wymieniano rozmaite czynniki), udzieliło 9 badanych. Gdyby założyć, że takie proporcje zachowałyby się w całej grupie około dwóch tysięcy studentów KAAFM, którzy przyjechali do nas z Ukrainy, to można by przypuszczać, że znaleźli oni swoje miejsce w Polsce, w Krakowie i w systemie polskiego i jednocześnie europejskiego szkolnictwa wyższego. Miejsce, które wielu z nich uznaje za swoje i z którym się utożsamia.

\section{W CZYM AKADEMIA MOŻE POMÓC I CO NALEŻY W NIEJ ZMIENIĆ}

Te dwa pytania zawarte w śródtytule miały charakter otwarty, zatem studenci mogli się całkowicie swobodnie wypowiedzieć. Rozrzut tematyczny jest dość duży i w kilku przypadkach te same problemy pojawiają się w odpowiedziach na oba pytania, co można rozumieć tak, że akademia może pomóc przez zmianę niektórych stanów obecnie istniejących i odczuwanych przez studentów jako niekorzystne.

Akademia może zatem wspierać:

- w zdobyciu dobrej wiedzy, zostaniu dobrym specjalistą, "godnym studentem Akademii" - 16 odpowiedzi,

- w znalezieniu pracy, np. poprzez zorganizowanie targów pracy 15 odpowiedzi, 
- w adaptacji do polskiej kultury - 13 odpowiedzi,

- w poprawie komunikacji między studentami i pracownikami uczelni, a także w usprawnieniu obiegu informacji - 10 odpowiedzi,

- w wyjeździe za granice, np. na program Erasmus - 8 odpowiedzi,

- w adaptacji studentów pierwszego semestru, np. poprzez ustanowienie opiekunów grup studenckich -6 odpowiedzi,

- w nauce języków obcych, w tym od poziomu zerowego-6 odpowiedzi,

- w nawiązaniu nowych znajomości i kontaktów - 4 odpowiedzi,

- we wprowadzeniu stypendiów dla studentów z Ukrainy - 4 odpowiedzi,

- w przyjęciu większej liczby studentów z Polski na kierunek stosunki międzynarodowe -2 odpowiedzi,

- w uzyskaniu europejskiego dyplomu - 2 odpowiedzi,

- oraz w 5 innych sprawach wymienianych w pojedynczych odpowiedziach.

Pięcioro respondentów sformułowanie „w czym może Panu/Pani pomóc nasza Akademia" zrozumiało jako pytanie o to, w jaki sposób sami mogą wesprzeć uczelnię, i zaoferowało pomoc $w$ informowaniu i promowaniu KAAFM w Ukrainie oraz reprezentowaniu akademii w dyscyplinach sportowych, które trenowali w swoim kraju rodzinnym i w których mieli znaczące osiągnięcia.

Przy pytaniu o to, co należy zmienić lub poprawić w KAAFM, aby podnieść jakość studiowania, rozkład odpowiedzi przedstawia się następująco:

- zwiększyć liczbę praktyk - 13 odpowiedzi,

- zwiększyć liczbę ofert na program Erasmus, rozwinąć współpracę międzynarodową - 13 odpowiedzi,

- zmienić harmonogram (stały rozkład, terminy egzaminów ustalać na początku semestru) - 12 odpowiedzi,

- poprawić sposób egzaminowania oraz oceniania studentów (np. wprowadzić ustne egzaminy z przedmiotów humanistycznych, wprowadzić kolokwia i inne sprawdziany w ciągu semestru) - 12 odpowiedzi,

- zwiększyć empatię i zrozumienie dla studentów cudzoziemców 8 odpowiedzi,

- niczego nie zmieniać, „wszystko jest normalnie” - 6 odpowiedzi,

- usprawnić pracę dziekanatu - 5 odpowiedzi,

- zmniejszyć liczbę niepotrzebnych przedmiotów - 5 odpowiedzi, 
- usprawnić pracę dziekanatu wirtualnego - 5 odpowiedzi,

- wpłynąć na zmianę stosunku niektórych wykładowców do dydakty$\mathrm{ki}-4$ odpowiedzi,

- wprowadzić obowiązkową obecność na wszystkich zajęciach, karać za nieobecności - 3 odpowiedzi,

- zindywidualizować programy studiów - 3 odpowiedzi,

- „zrozumieć sytuację Ukraińców, specyfikę ich problemów” - 3 odpowiedzi,

- wprowadzić USOS - 2 odpowiedzi,

- nadać zajęciom charakter interaktywny - 2 odpowiedzi,

- ustanowić stypendia sportowe - 2 odpowiedzi,

- wprowadzić egzaminy wstępne - 2 odpowiedzi,

- poprawić kompetencje językowe (angielski) niektórych wykładowców - 2 odpowiedzi,

- oraz wprowadzić 12 innych zmian sugerowanych przez pojedyncze odpowiedzi ${ }^{28}$.

Studenci z Ukrainy w większości czują się związani z akademią, pokładają w niej nadzieję i oczekują od niej pomocy. Najczęściej oczekiwania te dotyczą spraw prostych, niewymagających ani dodatkowych nakładów, ani przesadnych wysiłków ze strony administracji uczelni. Świadczy o tym choćby poniższa prośba członka jednego z kół naukowych działających „we Fryczu”:

Jestem członkiem koła naukowego, dlatego chciałbym prosić o pomoc ze strony Akademii. Czasami (gdy organizujemy szkolenia i inne wydarzenia) ciężko jest na przykład o zarezerwowanie sali. Proszę o współpracę, ona naprawdę jest bardzo potrzebna.

\section{UWAGI KOŃCOWE}

Były premier Wielkiej Brytanii Tony Blair zaproponował kiedyś ustalenie kryteriów podziału krajów świata na atrakcyjne i nieatrakcyjne. Krajami atrakcyjnymi miałyby być te, do których ludzie chcą przyjeżdżać. Natomiast

\footnotetext{
${ }^{28} \mathrm{Na}$ przykład: „nie kłamać o normalnym poziomie wykształcenia”, „podnieść prestiż uczelni i znaczenie wśród innych”, „upaństwowić”, „zabronić używania języka ukraińskiego i rosyjskiego na terenie uczelni”, „więcej zajęć z WF”, „mniejsze ceny w kafe i stołówce”, „akceptować karty kredytowe”, „bogaty księgozbiór w bibliotece”.
} 
krajami nieatrakcyjnymi pozostałyby te, z których ludzie chcą wyjeżdżać. Sądząc po wciąż dużym zainteresowaniu studiami w Polsce młodych obywateli różnych krajów, zwłaszcza z państw powstałych po rozpadzie ZSRR, a wśród nich przede wszystkim z Ukrainy, Polska jest krajem niezmiennie atrakcyjnym. Atrakcyjność ta ma jednak wiele twarzy.

Dla studentów z Ukrainy uczących się w Krakowskiej Akademii im. Andrzeja Frycza Modrzewskiego wynika ona przede wszystkim z członkostwa Polski w Unii Europejskiej, możliwości uzyskania na polskich uczelniach dyplomu uznawanego w całej Europie, otwarcia na Zachód czy wizy Schengen. Towarzyszy temu coś, co można nazwać immanentną atrakcyjnością Polski. Składa się na nią przekonanie o wysokim poziomie studiów w Polsce, przystępna cena studiów w Polsce w porównaniu z innymi krajami europejskimi, geograficzna bliskość Ukrainy, brak korupcji w porównaniu z Ukrainą, wyższy poziom życia, a także podobieństwo języka i kultury.

Wszystkie te atrybuty przyczyniają się do tego, że absolwenci ukraińskich szkół średnich za naturalny kierunek migracji edukacyjnej obrali Polskę. Według danych Fundacji Edukacyjnej Perspektywy z 11 kwietnia 2016 roku spośród 57119 studentów obcokrajowców uczących się w Polsce 30589 (53,6\%) stanowili obywatele Ukrainy ${ }^{29}$. Przyczyniają się oni do umiędzynarodowienia systemu szkolnictwa wyższego, w obliczu niżu demograficznego umożliwiają normalne funkcjonowanie wielu uczelni, mogą stać się ambasadorami kultury polskiej w świecie i spełniać wiele innych pożytecznych funkcji. Równocześnie jednak ich widoczna koncentracja na niektórych uczelniach wywołuje backlash - odruch sprzeciwu, na rosnącej fali postaw nacjonalistycznych skierowany przeciwko rzekomej ukrainizacji polskich uczelni.

W porównaniu z większością rozwiniętych krajów świata poziom internacjonalizacji studiów w Polsce jest wciąż bardzo mały, ponieważ studenci z zagranicy stanowią zaledwie $4 \%$ kształcących się na naszych uczelniach. Obecny minister nauki i szkolnictwa wyższego Jarosław Gowin w swym wystąpieniu z 20 października 2016 roku podczas konferencji poświęconej umiędzynarodowieniu polskich uczelni, zorganizowanej na Uniwersytecie Rzeszowskim, uznał nawet, że „umiędzynarodowienie jest [...] piętą

\footnotetext{
${ }^{29} \mathrm{https}$ //forumakademickie.pl/aktualnosci/2016/4/11/3489/juz-ponad-57-tysiecy-studentow-zagranicznych-w-polsce/ (dostęp 12 XI 2016).
} 
achillesową polskiego szkolnictwa wyższego"30. By tak nie było, jak zauważył minister:

Potrzebne jest zdecydowanie większe otwarcie się polskich uczelni na studentów z innych państw, a także przyciąganie naukowców z zagranicznych ośrodków - w tym Polaków, którzy osiągnęli sukces za granicą. [...] Nadeszła pora, aby po dwustu latach odwrócić wektor drenażu mózgów ${ }^{31}$.

W większości uczelni w Polsce proces umiędzynarodowienia zaczyna się od kształcenia studentów z Ukrainy. Oni też są nosicielami pierwszych masowych doświadczeń nauczania obcokrajowców w Polsce. Przypadek Krakowskiej Akademii im. Andrzeja Frycza Modrzewskiego jest jedną z wielu części tego procesu. Jest także przykładem uczestnictwa akademii w globalnych procesach migracyjnych. Przy uwzględnieniu takiej perspektywy tekst staje się zaproszeniem do dyskusji.

\section{BIBLIOGRAFIA}

Gordon M.M., Assimilation in American Life. The Role of Race, Religion, and National Origins, New York 1964.

Rokicki J., O realności i złudzeniu „globalizacji”, „wielokulturowości” i „ponowoczesności”, [w:] Wzory wielokulturowości we współczesnym świecie, red. K. Golemo, T. Paleczny, E. Wiącek, Kraków 2006, s. 25-38.

\section{Netografia}

Bańko M., W Ukrainie czy na Ukrainie?, http://sjp.pwn.pl/poradnia/haslo/w-Ukrainie-czy-na-Ukrainie;16214.html (dostęp 5 VI 2016).

http://naukawpolsce.pap.pl/aktualnosci/news,411703,gowin-umiedzynarodowienie-pieta-achillesowa-polskiego-szkolnictwa.html (dostęp 17 XI 2016).

http://www.ka.edu.pl/gfx/ksw/userfiles/rekrutacja/2014_2015/zarzadzenie_r.__kursy_j._ polskiego_dla_cudzoziemcow.pdf (dostęp 4 X 2016).

http://www.studyinpoland.pl/konsorcjum/images/stories/115_2015_newsletter/raport-studenci-zagraniczni-tabela.pdf (dostęp 7 IX 2016).

https://en.wikipedia.org/wiki/Culture_shock (dostęp 7 IX 2016).

https://forumakademickie.pl/aktualnosci/2016/4/11/3489/juz-ponad-57-tysiecy-studentow-zagranicznych-w-polsce/ (dostęp 12 XI 2016).

${ }^{30} \mathrm{http}: / /$ naukawpolsce.pap.pl/aktualnosci/news,411703,gowin-umiedzynarodowienie-pieta-achillesowa-polskiego-szkolnictwa.html (dostęp 17 XI 2016).

${ }^{31}$ Ibidem. 
https://pl.wikipedia.org/wiki/Karta_Polaka (dostęp 30 IX 2016).

https://pl.wikipedia.org/wiki/Poziom_bieg\%C5\%820\%C5\%9Bci_j\%C4\%99zykowej (dostęp 14 X 2016).

Kalervo Oberg, „American Anthropologist” 1974, nr 76 (2), http://onlinelibrary.wiley.com/

doi/10.1525/aa.1974.76.2.02a00260/pdf (dostęp 7 IX 2016).

\title{
MIGRATION, EDUCATION AND WORK. STUDENTS FROM UKRAINE IN ANDRZEJ FRYCZ MODRZEWSKI KRAKOW UNIVERSITY
}

\begin{abstract}
The paper presents results of the survey carried out by the author among students - citizens of Ukraine - who study at Andrzej Frycz Modrzewski Krakow University. The survey has been aimed not only at social and demographic profiling of the group, but also at outlining dominant reasons that encouraged young Ukrainian citizens to choose Poland, Krakow, and the Frycz Modrzewski University as their education centre; at assessing attractiveness of the studying, adaptation in a foreign country, contacts with the Poles both inside and outside of the academy. Based on the results of the survey the attractiveness of studies in Poland results from the membership of Poland in the European Union, recognition of the high level of education in Poland, relatively low costs of studies compared to the other European countries, and geographical and cultural proximity of Ukraine and Poland.
\end{abstract}

Key words: Ukrainian students, adaptation, study, Krakow 